\title{
Embodying Difference: Reading Gender in Women's Memoirs of Humanitarianism
}

DOI:

10.1080/17502977.2018.1482079

\section{Document Version}

Accepted author manuscript

Link to publication record in Manchester Research Explorer

\section{Citation for published version (APA):}

Read, R. (2018). Embodying Difference: Reading Gender in Women's Memoirs of Humanitarianism. Journal of Intervention and Statebuilding, 12(3), 300-318. https://doi.org/10.1080/17502977.2018.1482079

\section{Published in:}

Journal of Intervention and Statebuilding

\section{Citing this paper}

Please note that where the full-text provided on Manchester Research Explorer is the Author Accepted Manuscript or Proof version this may differ from the final Published version. If citing, it is advised that you check and use the publisher's definitive version.

\section{General rights}

Copyright and moral rights for the publications made accessible in the Research Explorer are retained by the authors and/or other copyright owners and it is a condition of accessing publications that users recognise and abide by the legal requirements associated with these rights.

\section{Takedown policy}

If you believe that this document breaches copyright please refer to the University of Manchester's Takedown Procedures [http://man.ac.uk/04Y6Bo] or contact uml.scholarlycommunications@manchester.ac.uk providing relevant details, so we can investigate your claim.

\section{OPEN ACCESS}




\section{Journal of Intervention and Statebuilding \\ Embodying difference: reading gender in women's memoirs of humanitarianism \\ --Manuscript Draft--}

Full Title:

Manuscript Number:

Article Type:

Keywords:

Abstract:

Order of Authors:

Response to Reviewers:
Embodying difference: reading gender in women's memoirs of humanitarianism

RISB-2017-0043R1

Special Issue Article

gender; difference; passing; embodiment; humanitarian; memoir

This paper seeks to explore what we can learn about embodied difference in humanitarianism and peacebuilding by taking seriously women's memoirs as a form of 'flesh witnessing' (Harari 2009). It argues that the essays in Chasing Misery (Hoppe 2014a) are simultaneously claims to the authority of 'The Field' but also reveal the sense to which the women feel they are only 'passing' as aid workers. I note three themes of difference, beginning with the construction of 'The Field' as a site of embodied authority and the ways in which the women's essays reinforce and trouble this. Secondly, the writers' feeling different from, and separate to, the people they work with and for. Finally, embodied gender presented with reference to imagined 'real' aid worker.

\section{Roisin Read}

I thank the reviewers for their helpful comments, I have addressed them as below:

1. Revision of the introduction - I have, as suggested, moved much of the conclusion to the introduction and included an outline of the article (1b). I have also included a separate section describing Chasing Misery (1a).

2. Discussion of the literature on women, bodies and aid work, especially Hannah Partis Jennings. I have looked at the suggested literature and incorporated it throughout the piece but also have highlighted it in the first paragraph of the introduction.

3. Move 'flesh witnessing' to the beginning of the section on 'difference, embodiment and passing' and expand on the method - I have moved it to the beginning of the section and expanded on the method.

4. Clarify what 'system' is being challenges in first paragraph 'Muzungus, gender and humanitarian exceptionalism' - changed to read: '...challenges the dominant humanitarian narratives, but ultimately ends up also reproducing them'

5. Deeper set of conclusions pulling out the broader importance the article - new conclusion written.

I look forward to your comments on the revised version. 


\title{
Embodying difference: reading gender in women's memoirs of humanitarianism
}

\author{
This paper seeks to explore what we can learn about embodied difference in \\ humanitarianism and peacebuilding by taking seriously women's memoirs as a \\ form of 'flesh witnessing' (Harari 2009). It argues that the essays in Chasing \\ Misery (Hoppe 2014a) are simultaneously claims to the authority of 'The Field' \\ but also reveal the sense to which the women feel they are only 'passing' as aid \\ workers. I note three themes of difference, beginning with the construction of \\ 'The Field' as a site of embodied authority and the ways in which the women's \\ essays reinforce and trouble this. Secondly, the writers' feeling different from, \\ and separate to, the people they work with and for. Finally, embodied gender \\ presented with reference to imagined 'real' aid worker.
}

Keywords: gender; difference; passing; embodiment; memoir, aid worker

\section{Introduction}

Humanity has long been cited as humanitarians' main constituency, yet, despite the obviously gendered nature of the humanity being discussed, the humanitarian sector (including academics) has been slow to make gender a central category of analysis. Gender has been a central aspect of humanitarian programming without key questions being asked about how gendered power relations shape the sector more broadly. As Miriam Ticktin notes $(2011,250)$, humanitarian discussions of humanity raise a central paradox of feminism, that 'one must emphasise one's difference (as women) in order to claim one's sameness (as equal human beings)'. This manifests in relation to 'debates about whether to include women as equal subjects/objects of humanitarian aid... or whether to single them out as different in order for them to receive critical attention and care' (ibid). Gender is a key category of difference in humanitarianism and peacebuilding but has tended to be overlooked in favour of discussions about the differences between the local and international (for exceptions see Partis-Jennings, 
2017; McLeod, 2015; and Martin de Almagro, this issue). In this paper, I seek to explore embodied accounts of difference in humanitarianism by considering Chasing Misery (Hoppe 2014a), an anthology of essays by female aid workers. I claim that we can learn about practices of humanitarianism and peacebuilding by taking these accounts seriously, not as objective truth, but as examples of 'flesh witnessing' (Harari, 2009).

As Duncanson notes $(2013,57)$ in relation to soldiers, there is something 'particularly revealing about identity' in memoirs which are 'their story as they want to tell it'. They can tell us about 'which embodied experiences become important', or more simple, 'whose bodies count' (Dyvik 2016a, 59). However, they are not just revealing about personal identities but also collective identity, these memoirs shape and are shaped by broader social imaginaries. imaginaries - following Lennon $(2015,1)$, the 'affectively laden patterns/images/forms, by means of which we experience the world, other people and ourselves' - which affect not only how aid workers and wider publics think about humanitarian aid, but also how they think about the spaces in which humanitarian aid is deployed and the people who receive it.

Humanitarians, especially in conflict-affected areas, increasingly serve as sources of knowledge about the areas they work and people they work with, as such it is important to critically interrogate their experiences and knowledge. How female aid workers narrate their experiences of the spaces of humanitarianism can offer important insights into the construction and maintenance of a distinctly humanitarian social imaginary. It also highlights the complex and intersecting hierarchies of gender, race, class, nationality and age which are deeply embedded in humanitarian practices. The 22 stories in the Chasing Misery (Hoppe 2014a) collection ${ }^{\mathrm{i}}$ frequently collapse public/private, work/life binaries in different ways. They address complex emotional 
and fundamentally sensorial experiences, often viscerally. Difference appears in the stories, in relation to colleagues, recipients of aid, parties to conflict and friends and family 'back home', but it is always embodied. This embodiment matters as there is always 'a tension between women's lived bodily experiences and the cultural meanings inscribed on the female body that always mediate those experiences' (Conboy, Medina and Stanbury 1997, 1).

In order to explore this tension, I read these stories through a double lens of 'flesh witnessing' and 'passing'. ${ }^{i i}$ In doing so, I address 'difference' in peacebuilding and humanitarianism as a gendered relation of power, highlighting three of the ways existing norms of what it means to be an aid worker produce the women as different such that they 'have to pass as what you are assumed not to be' (Ahmed 2017, 115). As such, the women must perform their identity as aid workers - to try to pass - because the legitimacy of their claim to the identity is in question (120). In drawing attention to the ways in which the identities are performed, it is possible to see how the norms which establish difference are both reinforced and contested. I will begin by arguing that the women's narrations of their experiences are claims to the authority of 'The Field'. Following this, I will highlight they ways in which the writers produce themselves as different to, and separated from, both the populations they are there to assist and their own communities 'back home'. Finally, I will show how the essays also reveal the sense many of the women experience of 'being inadequate to the identity' (Ahmed $1999,96)$ of aid worker. In taking the essays of women in aid work as a starting point I hope highlight the ways in which difference is always embodied and is imbued with meanings, whether somebody realises it, or not. Before outlining the approach I take to reading the women's essays, I will briefly introduce the anthology, Chasing Misery (Hoppe, 2014a). 


\section{Chasing Misery}

Published in 2014, Chasing Misery: an anthology of essays by women in humanitarian responses is edited by a team, led by Kelsey Hoppe, an aid worker with both humanitarian and development experience in a range of countries. She states that she developed the idea for the anthology 'as a way to give a platform to women's perspectives and voices in the work they do as well as to help people better understand what humanitarian aid is' (chasingmisery.net, n.d). The book has 24 essays written by 21 different women ${ }^{\mathrm{iii}}$, including a preface by Kelsey Hoppe (2014b). The women come from a variety of different backgrounds ${ }^{\mathrm{iv}}$ and have worked in humanitarianism in different roles and capacities.

The editor, Kelsey Hoppe, is explicit in her belief that women have distinct insights to offer; 'women's voices, perspectives and narratives on aid work are unique and deserve their own space'. She suggests this is in part because of their ability 'to explore the greys, the 'inbetweenness', to reflect on the questions about being human' (2014b, 12). The book starts from the assumption that women have a different perspective on the world, different, that is, presumably, to men. Feminism has long been interested in situated knowledges (Haraway 1988), and the book poses interesting questions about the liminality of women in humanitarianism and peacebuilding (for more on the liminality of women in peacebuilding see, Partis-Jennings 2017, 418). For endeavours which claim gender as a central policy and programming expertise, surprisingly little attention has been paid to the ways in which their everyday humanitarian practices are gendered, given the feminist underpinnings of the 'local' and 'experiential' turns, this oversight seems even more stark. 


\section{Difference, embodiment and passing}

Feminist approaches to international relations have, in recent years, highlighted the need for bodies to be brought inside 'the frame of international relations' (Wilcox 2015). This literature has tended to focus on the ways in which war needs to be understood as an embodied experience by 'centralizing people's experiences' (Dyvik 2016a, 56). I argue that extending this lens to peacebuilding and humanitarianism is a key move, as these activities are deeply embedded in conflict and, thus, are a key site of investigation for more fully understanding the lived experiences of conflicts and their aftermaths. Though there has been an experiential turn in the study of peacebuilding, much of this literature leaves the feminist origins of the move to the 'everyday' implicit and the analyses remain at a level of abstract from specific lived experiences which precludes an embodied analysis, though the work of Laura McLeod (2015); Hannah Partis-Jennings (2017) and Maria Martin de Almagro (2017 and this issue) are exceptions. As Christine Sylvester notes (2013, 5, emphasis in original), our experiences of war, and I would argue interventions in war, are 'experienced through the body', so we must look at the body as a unit of analysis. International aid workers in conflict settings have interesting and distinct experiences of war; they occupy a strange liminal position, in the conflict, but ostensibly not part of it. At risk, but also secured from violence. The lived experiences of these tensions can perhaps offer us insights into the broader dynamics of conflicts and the interventions which seek to end or ameliorate them.

Just as Duncanson (2009), Welland (2015) and Dyvick (2016a, 2016b) have looked to military memoirs to study the gendered performances at the heart of recent and contemporary conflicts, I argue that humanitarian memoirs can help us to explore the embodied racialised and gendered experiences of aid in conflict. I do not suggest that these memoirs can be seen unproblematically as 'true accounts', rather, following 
Duncanson $(2009,57)$, there is 'something particularly revealing about identity' in looking at personal narratives, 'their story as they want to tell it'. There seems to be a pervasive belief that there is something about the experience of being in these conflict spaces that is impossible to convey to those who have not experienced it; 'it is experienced by those who practice it as a bracketed space, one in which only a few have access to, at once a manifestation of life at its most real and its direct counterpart' (Dyvik 2016, 57). Yet, paradoxically, it is an elusive or illusory endeavour, as they will never fully be able to communicate the 'reality' of the experience.

As Catherine Baker $(2016,120)$ suggests, writing about embodiment is necessarily an act of both compression and translation, 'reducing the sensory complexity of someone else's physical experience, or even one's own, into written language that someone else will understand through sight or sound'. Yuval Noah Harari (2009) offers a way of thinking about this problematic through the notion of 'flesh witnessing', a phrase drawn from the observation of a French soldier from the First World War that one 'who has not understood with his flesh cannot talk to you about it [the experience of war]' (as quoted in Harari 2009, 215, emphasis in source).

The notion of flesh witnessing is especially intriguing in thinking about the humanitarian field as the idea of 'witnessing' and 'speaking out' has a controversial history in humanitarian aid interventions (for example, Givoni 2011). In contrasting flesh witnessing to eye witnessing, Harari $(2009,217)$ notes the different kind of authority associated with each. With eye witnessing, authority comes from the notion that you can observe 'facts' which can be verified. This relies on a mastery over a field of information that humanitarians rarely have more than partial access to. Flesh witnessing, on the other hand, offers a more "novel authority... which is based not on the observation of facts but on having undergone personal experience'. Harari notes that 
flesh witness accounts seem to be interested in conveying experiences but because they do not believe these experiences can be conveyed to those who have not had the same experiences, 'by definition, they cannot succeed in this' (221). Instead, 'flesh witness narratives are mainly an exercise in authority' (222). As Dyvik notes of military memoirs, they seem to convey 'you don't know what it's like', while attempting to tell the reader any way (Dyvik, 2016a: 58), as such, what they establish is the authority of the speaker.

Humanitarian memoirs are not only important for what they reveal about specific humanitarian experiences, but also for how they frame a broader social imaginary of what humanitarianism is. As Dyvik notes (2016a, 58), military memoirs are more than individual stories, 'these texts participate in the writing of war. They help frame what we think war is'. Similarly, humanitarian memoirs participate in the writing of humanitarianism and help us from what we think humanitarianism is. At the beginning of 2000s, David Reiff $(2002,87)$ critiqued the portrayal of humanitarianism which relied on a 'familiar morality play of victims in need and aid workers who stand ready to help if their passage can be secured and their safety maintained'. This remains a common (and deeply gendered) trope in humanitarian imagery.

Michel Agier $(2010,32)$ notes, '[t]he humanitarian world is based upon the fiction of humanity as an identity'. This identity draws legitimacy from a mythologised humanitarian history and legacy in which 'humanitarian exceptionalism' is entrenched in a particular reading of international humanitarian law (Fast 2014). However, as Ticktin (2011) notes in relation to humanitarian efforts to address sexual violence, the human upon which humanitarians have built their identity is gendered and racialised. She argues that the expansion of the humanitarian mission to include gender-based violence 'has inadvertently opened up space for confrontation with politically 
significant forms of difference and inequality' (262). I argue that humanitarian memoirs, as a form of 'flesh witnessing' (Harari 2008), offer an interesting way of thinking about difference as embodied.

When difference appears in discussions of peacebuilding, the most common difference cited is between the local and the international, as Lisa Smirl (2012) explored in relation to liminality in humanitarian memoirs. This binary is so embedded within peacebuilding literature that a subfield of literature has emerged to explore how it can be broken down through notions of hybridity (see for example, Mac Ginty 2010; Mac Ginty \& Richmond 2015). Concurrently, in discussions of aid worker security particularly, there has been recognition that there currently exists a 'humanitarian exceptionalism' (Fast 2014), whereby the 'expat' aid worker's status is rendered as something distinct from military or civilian; reinforced by their distinct security practices (Duffield 2010). The 'local turn' in peacebuilding has sought to challenge the dominance of international knowledge in both academic literature and practices of peacebuilding, yet in doing so has reinforced the distinction between local and international (Randazzo 2016).

As Bargués-Pedreny and Mathieu (this issue) note, within this hybridity literature;

differences are reified and essentialised as inescapable, but also, and perhaps more importantly, difference is linked to stigma (as a deviance from the 'normal' that is reproduced by the frames used to identify it)... emphasising difference (even as something to be celebrated, a space to cultivate bottom-up peace initiatives) does not remove the stigma attached to it insofar as the 'norm' is not questioned nor displaced.

Drawing on a different reading of hybridity in the work of Sara Ahmed (1999, 88, emphasis added), she talks of hybridization in the context of racial identity, as the 
rejection of the notion that two racial identities 'can be distinguishable in space and time: hybridization as the very temporality of passing through and between identity itself without origin or arrival'. Bargués-Pedreny and Mathieu (this issue), following Minow, suggest that we need to pay greater attention to the power relations which produce differences which then are presented as already existing, they call for us to see 'to how differences lie between people and not within them'. Passing offers a useful way of thinking about difference in this way, as it involves social differentiation which looks at structural rather than essential difference and invites the 're-opening or restaging of a fractured history of identifications' (Ahmed 1999, 93).

Building on Ahmed's $(1999,93)$ consideration of passing - which explores passing in relation to racial and sexual identity - it is only 'ambiguous exceptional bodies' whose difference is remarked upon. Aid workers have, in discourses of peacebuilding, been presented as exceptional 'international' bodies, in contrast to an often homogenised 'local'. Yet, this exceptional category - of international aid worker has also tended to be treated as homogenous. The implication is that their status as 'aid worker' overwrites all other kinds of difference, for example gender, race, class, nationality and religion. This is partly a consequence of the tendency to study humanitarianism as a disembodied organisational practice.

Partis-Jennings' (2017: 418) discussion of the 'third sex' - 'hybrid bodies, which were marked as both female and foreign, both vulnerable and powerful' highlights how a focus on gender and embodied affective experiences troubles the notion that 'international' actors can be seen as a collective category. In this paper, insisting on humanitarianism as an embodied practice allows for the differences between those international aid workers to be interrogated, and the implications of the power relations which produce these differences to be questioned. While the focus here 
is on embodied difference as narrated by the 'flesh witness' accounts, there is also a need to consider, as Joseph (this issue, ?) warns, 'the underlying social structures that, in a sense, make experience and performance possible as well as imposing constraints on it'.

As this section has outlined, the notion of flesh witnessing offers a way of reading the accounts of the women in the anthology as establishing their authority to speak about humanitarianism. However, at the same time as conveying the authority of 'The Field', the essays can also be read through the lens of passing. Just as Ahmed (1999) suggests that passing is both an 'act of moving through space' and 'a set of cultural and embodied practices', in the essays, the women writing are 'passing through' the places they write about as well as 'passing as' aid workers by embodying as set of practices which encourage the reader to view them as such. Likewise, just as they do not come to inhabit the places they pass through, as we will see, they also do not come to fully inhabit the identity of 'aid worker'. Rather, their 'passing' as aid workers is troubled by their identity as women.

The stories seem to serve to re-enforce the identity politics of aid. This is a politics, as Melissa Philips’s $(2014,27)$ essay ‘Real Women in Aid Work: Must we Be Either Angelina Jolie or Mother Theresa?' states, in which there are only a limited number of dominant interpretive schema for aid workers - either saints and saviours or 'missionary, mad, or misfit'. In these schema, the common assumption is that the aid worker is male. The stories then occupy an uneasy position, conveying the sense in which the women experience exclusion from the aid worker identity while also speaking with the authority granted them by their 'flesh witnessing' as aid workers. It is with the notion of these accounts as conveying authority that my analysis of the essays from Chasing Misery will begin. 


\section{The authority of 'The Field'}

As the previous sections have highlighted, thinking about the women's essays through the lens of flesh witnessing allows them to be viewed as accounts which establish the authority of the teller to speak about the humanitarian experience. One of the key ways this manifests in the story is through the reference to 'The Field'. As Helen Seeger (2014, 31) observes in her essay 'The Field: The Ever Receeding Vanishing Point', there is an authenticity that comes through discomfort in the aid worker sector; your recognition by your peers is 'directly proportional to how authentically grubby, sweaty, sunburnt and sleep deprived her or she is'. This hierarchy operates, Seeger adds, through an aid worker's 'proximity to a mythical place called 'The Field'. In the essay, Seeger sardonically charts her elusive and on-going search for a place called 'The Field' across deployments and projects which always seems to be 'somewhere else, just down the road (31).

This view echoes the work of Lisa Smirl $(2012,237)$ who refers to 'The Field' as a liminal space, in which 'spaces of work and play blend into one', totally collapsing any public/private distinction. As Richmond, Kappler and Björkdahl $(2015,24)$ have argued, the field is a label which is used extensively in peacebuilding, development and research to 'label a discursive and geographical space different from their own'. This difference is essential to the construction of the discursive frame of the field, Richmond, Kappler and Björkdahl suggest that the most obvious link is agrarian, fields which are farmed by peasants (25), but I suggest, in humanitarian and peacebuilding settings, the uses of this phrase owes more to military terminology, as it is usually accompanied by the terminology, security protocols and fashion, as will be discussed later, of 'deployment'. 
The imagined space of 'The Field' is, then, the site of authentic flesh witnessing, and just as this can never truly convey the experience of aid, the frame of 'The Field' discursively replicates this distance and Othering, as it is a space which cannot be truly reached. Borrowing Seeger's words; 'The field is in [insert dustier place], where Aid Workers are Aid Workers' (2014, 32). Sheehan explicitly refers to Darfur, her 'Field', as 'No Place' (2014). 'The Field' is a 'bracketed space' of the kind Dyvik notes (2016a, 57), inaccessible and filled with life at its most real due to the risk of death. It is especially inaccessible to international aid workers, as Seeger suggests $(2014,35)$, due to security concerns. However, this only seems to make it a more desirable location; supporting Roth's analysis $(2014,140)$ of aid as voluntary risk-taking or 'work that requires negotiating the edge'.

Other essays in the collection comment on features of 'The Field', and one of the most common and recurring features is the $4 \times 4$ or sports utility vehicle (SUV). As Lisa Smirl (2008; 2015; 2016), Mark Duffield (2010; 2012) and others (Abdelnour \& Saeed 2014; Autesserre 2014; Donovan 2015; Redfield 2016; Scott-Smith 2013) have highlighted, the physical spaces and material practices of aid work in recent years have functioned to create further distance between international aid workers and the populations of the countries they are resident in. The SUV is the main mode of accessing the field but it also represents the distance from it. As Mia Ali’s $(2014,52)$ essay, 'Built to Carry Thirteen', powerfully puts it 'I'm too busy helping beneficiaries to help the people by the side of the road'. She highlights the distancing effect of being in the $4 x 4$, separated from (both physically and emotionally), those populations they claim to assist.

Research by Donovan $(2015,740)$ also addresses the $4 \times 4$ suggesting that, 'the functionality of the $4 \times 4$ allows those with access to move about more fluidly' (to pass 
through), but it also renders the aid worker 'as more secure - even more dangerous - as the vehicle hurtles through the bush'. While some of the essays draw attention to the relative security and mobility the 4x4s provide the passenger - Tracy O'Heir's (2014, 73-74) 'Beating The Odds' notes the absence of safety felt when the promised NGO $4 \times 4$ does not arrive to pick her up - in the main, the experiences of the women in relation to the security and danger of the $4 \times 4$ are much more ambiguous, troubling the dominant narrative of 'bunkerisation' (see for example, Duffield 2010).

Rachael Hubbard's $(2014,152)$ essay 'The Great North Road', flips this idea of the vehicle as a site of security as she recounts 'the day I almost died on the Great North Road'. The Land Rover in her story is a space of 'torture' (151), as she is loaded into the, prone to breaking down, vehicle feverish with malaria. In this moment, she questions the profession: 'Is this what it meant to serve mankind? Watching children starve, watching babies die, fever, exhaustion, and fighting to breathe?' (157) but ultimately concludes that the experience has 'much to offer and much to teach' (159). Ruth Townley $(2014,127)$ begins her essay, 'Holding Their Stories', in a Toyota Hilux 'hurtling down a claustrophobic dirt road' with her seat belt unbuckled as her driver tells her the extra time it takes to 'takes to unbuckle can make the difference between life and death', the present danger of ambush clear in remains of a previous unlucky vehicle from her NGO they pass.

Mac Ginty (2017) has explored the value of the $4 x 4$ s to the conflict in Darfur, and Kelsey Hoppe (2014e) picks up this theme in her essay 'I Know What Fear Tastes Like'. She recounts the 'Gereida incident' from her time in Darfur. The incident sticks in her mind because of the 'brutality against NGOs themselves' (210), a night in which a rebel group attacked an NGO compound, stole vehicles, communications equipment and attacked Sudansese staff (211). She recalls another 'incident' in which a driver is 
killed, staff missing and 'vehicles had been torched' (213-214), again, countering the prevalent discourse that the ever present $4 \times 4$ is a site of security for aid workers, these women's flesh-witnessing challenges the unproblematic notion that for those international actors involved in intervention; 'exclusive transport links into an archipelago of protected international space' (Duffield 2010, 71).

Carmen Sheehan (2014) in her essay 'No Place', also about Darfur, draws attention to another danger experienced in relation to the $4 \times 4$, that of the road block/check point which also appears in Kirsten Hagon's essay, “There Is No Rape In Darfur" (2014). Sheehan describes being stopped at a check point shortly before curfew, her inner monologue, courtesy of her security training, highlights a very specific fear from the previous week's security briefing of an attempted rape of a female driver at a checkpoint after dark (234-235). In the essay, Sheenan collapses mind/body and internal/external distinction as the reader gets the physical and mental manifestation of her fear simultaneously, alongside the description of the interaction at the check point: 'Willing the motor not to die, I backed gently out into the road and glanced in the rear view mirror. If the firing squad in the road kept it together I would be free' (237). This highlights the way gender impacts feelings of security, a key theme of Partis-Jennings' (2017) work on gendered (in)security in Afghanistan.

The distance which the women report feeling in 'The Field' is not simply physical, represented by the separation of the $4 \times 4$, or in the material difference in the lives of international aid workers. It is also an emotional distance, as Lucy O’Donoghue's (2014) essay 'Relationships: At the heart of, well, everything' makes apparent. She compares the 'years of a transitory lifestyle' of the international aid worker to 'the relative stability that our local staff often have through their communities and families' (84). Again we see that these women are simply passing through, their 
difference allows them this privilege which also creates distance. She highlights this 'vacuum' as a 'lack' on the part of international aid workers (85). Interestingly, O’Donoghue (85) suggests a need for the building of relationships to reduce the 'gaping chasm of otherness found between expatriate and national staff', through a recognition of the embodied humanness of the Other; 'being human, recognising our need to give ourselves in relationship and in community.' This is not a vision of an idealised local community, but a recognition that local staff 'rarely got the opportunity to compartmentalise their lives'. In contrast, in the bracketed, liminal space of 'The Field', international aid workers are 'thoroughly unmoored' (80) from not only the communities they are present to assist but also from their own communities back home, and in some cases, their own emotions.

The nomadic lifestyle of the international aid worker is a key narrative through which difference is produced. O’Donoghue notes how 'bizarre' it must appear to local staff that 'we, the expatriates, would forfeit out own natural environment and longstanding relationships to insert ourselves, usefully or otherwise, into their relatively insecure world' (81, emphasis added). Through the notion of the 'natural' environment being other than the field, the difference of the international aid worker is reproduced. Yet, common to many humanitarian memoirs is the trope of alienation from 'home', both while in the field and especially once returning to 'normal' life.

This paradox at once produces 'The Field' as exceptional but also as real in a way that ordinary life is not. It is a place people need to return to in order to feel fully alive; as Emilie J. Greenhalgh $(2014,178)$ puts it in her essay 'Answers Found In Harm's Way: From Congo to Afghanistan'; ‘

I had not been able to find a balance between the fascination of the crisis, the romance of the humanitarian work, and the blatant desire of a twenty-something 
woman to have fun and not simply revel in chasing the misery the world dishes out every goddamn day'.

'Chasing Misery' is also the title of another of Kelsey Hoppe's essays and it picks up this theme, the desire to experience, as much as possible, the thrill and romance of the field.

The sacrificing of comfort and relationships, which will be explored further shortly, in pursuit of this nebulous idea of authenticity, of 'real' aid work comes up in Hoppe's (2014c, 21) essay, as she notes:

We parade through life dressed in immortality. Traipsing around places where it is likely that we will be shot or drowned or kidnapped or beheaded by people who believe things a little too much. Trying our immortality on for size, like new clothes, seeing if it fits. It never does. Immortality never fits anyone.

Again, there is a recurring sense of the illusiveness of the authenticity of experience which is being sought. The metaphor of clothes ${ }^{v}$ and their fit resonates with Ahmed's $(2017,125)$ comments on institutional passing, that 'an institution is like an old garment. It acquires the shape of those who tend to wear it; it becomes easier to wear if you have that shape'. Even as their experiences of the field allow them to speak with its authority, there is a sense of alienation from the identity they are trying (and failing) to inhabit. It does not quite fit and they do not quite fit in it; 'The Field' is always elsewhere, but this only serves to make the search for it more insistent. Thinking about this through the lens of passing highlights the ways in which the women in their essays simultaneously recognise the problematic authority of 'The Field' and also reproduce it, as Robinson $(1994,735)$ suggests, '[t]he limited subversion of the pass always requires the terms of the system be intact'.

This section has sought to explore the locus of authentic experience, as told in the essays of Chasing Misery (Hoppe 2014a). As a bracketed space to which others do 
not have access, 'The Field' serves as a space of authenticity of which only flesh witnesses can speak. However, the narratives offered in the collection both reproduce and trouble this notion, highlighting the ways in which this space is always out of reach. Indeed, this elusive quality is no doubt part of its appeal. They also highlighted the 'inbetweeness' of occupying this space 'unmoored' (O’Donoghue 2014, 80; Older 2014,300 ) from relationships which give meaning and thus fostering a search for meaning through 'chasing misery'. The next section will pick up on this notion of 'inbetweeness' and explore the ways in which race and gender appear in the women's narratives and can reinforce and trouble notions of 'humanitarian exceptionalism' (Fast 2014).

\section{'Muzungus', gender and humanitarian exceptionalism}

In the previous section, I noted that the limited subversion of the essays in the book challenges the dominant humanitarian narratives, but ultimately ends up also reproducing them. The essays in the book challenge, reflect on and reproduce the humanitarian system. Humanitarian memoirs are not only important for what they reveal about the humanitarian experience and imaginary, but also for how they frame for a broader social imaginary what humanitarianism is.

In her essay, 'Of Pastries, Loss and Pride', Kati Woronka (2014) notes the divide between international aid workers and 'Beneficiaries' the optimistic name 'we aid workers call the people we help' (Seeger 2014, 32). Woronka, describes this feeling of divide, noting in particular the generalising names that come to define them in different places; 'I felt a terrible divide between expatriates, including myself, and the people we were there to serve. There was always a name for us: Malae in East Timor, Blancs in Haiti, Khawaja in Darfur' (2014, 118-119). Miranda Gaanderse's (2014, 144) essay 'Send In The Clown' notes, of her experience working with Unaccompanied 
Minors in Uganda, the "personal victory that they now call by name rather than 'Muzungu’'.

Yet, some of the authors also fall into this trap, referring to themselves as 'expatriates' (see, O’Donoghue 2014; Woronka 2014) or 'expats' (see, Feldacker 2014; Greenhalgh 2014), explicitly placing themselves into an 'us' group which is contrasted with the 'them' of the intervention zone. As Woronka $(2014,119)$ suggests, this grouping seemed 'somehow inevitable: to the people we came to serve, we weren't individuals. We were foreign objects. And, no doubt, our hosts figured we felt the same about them. Maybe we did'. As Smirl has argued (2012, 230), it is in the everyday practices of 'The Field' and 'their accompanying spaces (the offices, compounds, workshops, projects) that the categories of local and international are (re)produced despite rhetorical commitments to move beyond them'.

This separation, as mentioned above, operates on more than one level, as the lifestyle of aid workers operates with a sense of separation from both home and those with them in 'The Field'. Just as there is 'always a name for us' (Woronka 2014, 118), the writers produce this same difference from 'nameless and faceless beneficiaries' (O’Donoghue 2014, 85). However, some also try to disrupt its Othering power; 'Doctors, lawyers and academics. Artists, musicians and poets. These were the 'beneficiaries"' (Woronka, 2014, 118). Seeger $(2014,34)$ highlights and satirises the use of generic terms like 'Beneficiaries' or 'The Community Leaders' to render difference, noting they are remote from the aid worker party scene and must surely 'not have such a strong affection for the Black Eyed Peas'. The subtext, they are not like 'us'.

As Miranda Bryant $(2014,43)$ tells us in her essay 'From New Orleans to South Sudan: How I Healed by Moving to a War-Torn Country', the distancing effect of working in a 'field' overseas can be easier as there is an emotional distance which 
comes with the ability to withdraw, they can 'can buffer themselves from the pain of their beneficiaries experience by virtue of understanding that, theoretically, they can board a plane and leave the disaster when they so choose'. Here it is interesting to note that it is the pain of the experiences that Bryant notes that they are buffered from, while other stories make clear that the difference and separation from the people occupying the spaces in which they work is much deeper and more entrenched.

A number of the essays note the lack of understanding from 'locals' (both staff and otherwise) who question the lifestyle choice to be an 'expat' aid worker (for example, O’Donoghue 2014, 82). Here gender seems to play an especially important role, particularly the impact of the lifestyle on relationships. In 'Home is Where the Hard is' Caryl Feldacker $(2014,261)$ describes the end of her 'unsalvageable' engagement while in Malawi ${ }^{6}$, a recurring theme in the essay is the way the engagement 'legitimised our partnership and gave me additional credibility' (263) in the context of the religious conservatism of Malawi. The difference in lifestyle between the motherhood of the 'beneficiaries', repeatedly referenced across the essays, and the decision on the part of the female aid workers to live 'unmoored' lives is a key source of difference, though only rarely explicitly addressed, such as Woronka's $(2014,178)$. regret that; 'I regretted that I had never been married or even been in a serious relationship'.

Romantic relationships (and the lack of them) are a common theme running through a number of the essays, as well as the relationship (or lack of) between the writers and their colleagues and 'beneficiaries'. Reflecting on her own unwillingness to follow her partner to Vancouver, Kelsey Hoppe (2014c, 23) considers the difficulty of connecting to someone else romantically may be part of what inspires her to chase misery: 
We are not the sort of people who go places for other people. We are not people who need others to come and be where we are. This is what makes us so interesting. This is what makes us think we are in love with each other when we are not. We are in love with ourselves. We are in love with the idea of ourselves. It is actually a mad grasping fit of jealousy that we mistake as love when we see our lives being lived by another.

The idea of seeing 'our lives being lived by another' picks up on a theme explored in the passing literature, that of 'in-group' recognition: that is recognition from the group one has passed from (Robinson 1994). The women's stories in the book perform this function, the women's recognition of each other's passing as aid workers validates their own passing, and their claims to authority. In this way, similar to Sue-Ellen Case's observation of the butch-femme aesthetic $(1988,70)$, 'a strategy of appearances replaces a claim to truth'.

Lucy O'Donoghue's $(2014,80)$ description of aid workers who have 'thoroughly unmoored themselves', who seem 'adrift from any community, at home or on mission', is an interesting counterpoint to Roberta Romano's 'The Subtle Thread' (2014). Romano's essay addresses a growing sense of questioning, found also in Greenhalgh's $(2014,171)$ essay; 'The romance had left almost the instant I arrived, quickly replaces with the feeling of futility that we all tried to forget while commiserating at the local expat bars'. Lisa Smirl (2012) also observed this phenomena in the humanitarian memoirs she analysed; 'as they begin to realise that they are all in a state of ineffectual limbo, where none of their efforts have any impact'.

As this paper has shown, across the essays we see that the female aid worker is always Other, even in their own accounts. Different to, and separated from, those populations they claim to assist and their lives 'back home', searching for the authenticity of experience of 'The Field', and the clarity and validation which its dangers and risks can provide. The following section will explore the sense in which the 
essays highlight the ways the women experience the difference of being female in a profession in which 'most of these stereotypes rest on the assumption that aid workers are male' (Philips 2014, 26).

\section{Passing as an aid worker}

The essays discussed in this paper do not exist in a vacuum, there are broader discourse and narratives from which the writers draw and to which the writers contribute; social imaginaries of the humanitarian sector are already present (for example, see Dechaine 2002; Repo \& Yrjölä 2011). In thinking about the embodied experience of female aid workers, it is necessary to explore how bodies become intelligible in relation to broader discourses and structures. As mentioned earlier, Phillips $(2014,27)$ highlights that the common assumption is that the aid worker is male. The women in the essays confirm this sense of only 'passing as' aid workers in relation to the 'real' (male) aid workers, this sense of being out of place as a women in the essays is linked to notions of their newness, inexperience and lack (or not) of toughness.

Philips $(2014,25)$ communicates this through the story of her experience at Nairobi's Jomo Kenyatta airport, where she thought she 'had ended my aid career before it even began' over an alarm clock which 'looked suspiciously like handcuffs' on the security x-ray. It is not the situation but Philips's (25) reaction to it which causes the problem, 'I was surrounded by other conflict-weary, khaki-wearing aid workers who were mostly men and I feared I had committed a fatal error [crying] that highlighted both my newness and my gender'. For Philips, her gender is a deficiency for humanitarian work on a par with her lack of experience. It is not simply the fact of her gender, but the physical manifestation of this in her tears and near-hysteria. She has failed to pass in this instance and the manner of her failure highlights that the 'sense of 
being inadequate to the identity one assumes (either consciously or unconsciously) involves phantasies about who is the real or authentic subject' (Ahmed 1999, 96). In the essays, we repeatedly see fantasies about what authenticates a 'real' aid worker.

Again, difference is produced for the women in their stories through juxtaposing their extraordinary lives to the lives of those around them as well as to the more experienced, more 'real' aid workers. Gaanderse $(2014,137)$ tackles this in her essay in which she found herself, 'the girl from headquarters who was bringing a whole household with her to a refugee settlement' subject to the 'mocking stares and incredulous glances - especially from local male colleagues'. She recalls thinking 'I am tougher than they think'. The issue of 'toughness' as a norm or standard of what makes a 'real' aid worker also appears in O'Donoghue's $(2014,79)$ essay. She notes the persona she tried to embody, 'a fusion of ruthless efficiency and hakuna matata, and it felt like the result was one scratchy, cynical, impatient bitch'. This strategy of passing is common, 'a technique of the self' (Ahmed 1999, 101) in which the passer adopts elements of the identity one is trying to pass as and projects a particular bodily image. In describing the attempts of the women to adopt the identity of aid worker, the stories reveal the fetish of the aid worker identity. The women do the work of identifying the elements of the identity which reveal difference from their own; in 'desiring to capture an identity...[i]t takes time and knowledge to see the difference that one may desire (or need) to become' (98).

Seeger $(2014,31)$ highlights an important aspect of the notion of 'realness' in relation to aid work: its relationship to a specific aesthetic of dustiness and dirt. She highlights this, noting the 'professional suicide' of a stylish haircut which a 'real' aid worker would not have time for. The spectre of 'real' (masculine) aid workers haunts ${ }^{\mathrm{vi}}$ many of the stories. For Philips $(2014,25)$, it was the khaki-wearing (male) veteran aid 
workers at the airport who seems to share much in common with Romano's $(2014,201)$ Austrian 'security guy that wears trousers full of pockets and you are sure he keeps knives and compasses in some of them'. Seeger $(2014,32)$ speaks of the 'infamous [Russian] helicopter pilots about whom every veteran aid worker seems to have a story'. For Roberson $(2014,62)$ it is the 'big, burly South African and Zimbabwean ex-military men, who knew how to drink and have more fun than anyone else I have ever met' from the landmine NGO. And for Greenhalgh $(2014,173)$, it was the 'WPF guys [who] tolerated our presence, using it as a chance to gossip and flirt'.

As Ahmed $(2017,122)$ notes of passing, 'it can be uncomfortable' to not be able to embody established norms and the discomfort of the failure to pass can also be found in the essays, often made visible by the specific discomforts of female aid workers. This is a theme also explored in Partis-Jennings' $(2017,418)$, account of the gendered security practices of peacebuilding in Afghanistan, in which many highlighted 'restriction, harassment or self-enforces security measures based on gender'. Greenhalgh $(2014,172)$ supplements the general discomfort of 'The Field' with the particular discomfort of being a woman there; the 'unfriendly locals who catcalled'. Gaanderse also highlights this $(2014,138-139)$, she describes the awkwardness of the showers being situated next to the contingent of the Uganda Police Force, there to protect them, as she 'began to wonder whether stripping down in the dark next to a group of half-drunk, undressed, male police officers was really such a good idea.'

A similar problem is observed in Ali's essay $(2014,51)$, in which she is hungry and thirsty 'but what goes in must come out, and there's no privacy for a woman at the side of these roads'. Ali's dilemma is compounded by the threat of landmines away from the road where privacy could be found. My intent here is not to claim that women have it worse, but to draw attention to the specific and embodied differences which alter 
how they experience 'The Field' and to suggest that we need to ask more about these differences and the effects they have on practices of peacebuilding and humanitarianism.

As Phillips' story of her airport experience highlights, women's apparent propensity for tears marks them as different. As Hoppe $(2014,12)$ notes in the preface to the book, 'women are more apt to cry, or at least admit to crying', however, she frames this as 'often the only appropriate response' to human suffering. Yet, it is often the personal miseries in the essays which lead to tears: Philips at the airport; Woronka falling out with a colleague (2014); Gaanderse $(2014,135)$ 'the crying aid worker', emotional at leaving; and Hoppe $(2014,220)$ with relief at seeing a colleague during a difficult time.

The juxtaposition between tears as the appropriate response to human misery and the actual instances of their own crying detailed by the women reflects the concern, discussed in the preface to Chasing Misery, that telling the aid worker story 'detracts from the stories of those we have gone to help or those who are 'truly' suffering' (Hoppe 2014b, 11-12). The goal of the book, to stand in solidarity with those 'truly' suffering by attempting to 'tell your story through my story' (12), presents a community in which crying is affirmed as an 'appropriate' response, and in doing so the authors also affirm their membership of a community of female aid workers. This affords them a collective voice through which they challenges the assumed superiority of the masculinity and 'maleness' of the aid worker identity, from a position of authority which their experience of 'The Field' grants them.

\section{Concluding thoughts: women as flesh witnesses in humanitarianism}

This paper explores what we can learn about embodied difference in humanitarianism and peacebuilding by taking seriously women's memoirs as a form of 'flesh witnessing' 
(Harari 2009). A focus on humanitarian memoirs, representing "their story as they want to tell it' (Duncanson 2013, 57), builds on the important feminist research done on military memoirs, especially Dyvick (2016a; 2016b; see also, Welland 2015;

Duncanson 2009); embodiment in peace and conflict studies (Partis-Jennings 2017; Wilcox 2015; Sylvester, 2013); and Lisa Smirl's work on liminality in humanitarian memoirs (Smirl 2012). Drawing on the notion of 'flesh witnessing', I have argued that the essays in Chasing Misery (Hoppe 2014a) collection are simultaneously claims to speak with authority of 'The Field' but also reveal the sense to which the women feel they are only 'passing' as aid workers.

In this paper, I noted in particular three themes of difference, beginning with the construction of 'The Field' as a site of embodied authority and explored the ways in which the women's essays reinforced and troubled this notion. I then noted the ways in which the writers highlighted feeling different from, and separate to, the people they work with and for. They highlight the generalising terminology and the effect of this on the possibility of forming genuine relationships. Relationships are also foregrounded as a site of difference but very much connected to their identity as aid workers 'chasing misery'. Finally, I explored the ways in which their embodied gender caused the writers to note their difference from an imagined aid worker, revealing a sense in which the women were only passing as aid workers. The fragility of the imagined identity itself is thus revealed in the collective narration of their experiences as female aid workers.

The article makes an original contribution to the literature on humanitarianism and peacebuilding, drawing on the under-researched humanitarian memoir. In doing so it highlights the curious absence of analyses of humanitarian aid which take gender seriously as a category of analysis, rather than simply a programming area. In highlighting the attempts of female aid workers to narrate their distinct experiences, it 
foreground embodied experience as key to a consideration of the complex power structures and relationships in humanitarianism and peacebuilding. The tendency to view the international/local distinction as the primary category of difference in humanitarianism and peacebuilding, obscures the complex and intersecting hierarchies of gender, race, class, nationality and age which are deeply embedded in humanitarian practices. Though the focus here has been on how gender difference is narrated by female aid workers as a starting point, analyses of this kind can also reveal important insights about these other categories of difference.

As a final point, I want to note that these memoirs must be viewed as shaping and shaped by broader social imaginaries. Just as explorers' travel writing has 'produced the rest of the world' for European audiences since the 1700s (Pratt 2008, 5), because "it functions to introduce "us" to the Other. This equally affords us a way of knowing ourselves' (Heron, 2007: 3). Memoirs of humanitarianism and peacebuilding perform the same function, introducing humanitarian spaces to Northern audiences, in order that they are reassured that 'Northern countries have a special role to play in alleviating the woes of the poor global others' (ibid, 5). Yet, while the essays in Chasing Misery (Hoppe 2014a) perform this function, and are firmly embedded in global structures and relationships of power, and this analysis has demonstrated the ways in which the women also trouble these discourses, by recognising them at work. By focusing on gender as a site of difference, the women present a community which affords them a collective voice through which they challenge dominant tropes of aid, from a position of authority which their experience of 'The Field' grants them. In doing so, they trouble the dominant narrative of noble aid workers, by recognising the paradox of self-fulfilment they receive from their apparent altruism, as Kelsey Hoppe puts it (2014c, 23), 'We are in love with ourselves. We are in love with the idea of ourselves.' 
The book sought to stand in solidarity with those 'truly' suffering by attempting to 'tell your story through my story' (12), but cannot escape from the dynamics of difference and Othering which plague the humanitarian system.

\section{References}

Abdelnour, S., and A. M. Saeed. 2014. “Technologizing Humanitarian Space: Darfur Advocacy and the Rape-Stove Panacea.” International Political Sociology, 8(2): 145-163. http://doi.org/10.1111/ips.12049

Agier, M. 2010. "Humanity as an Identity and Its Political Effects (A Note on Camps and Humanitarian Government)". Humanity: An International Journal of Human Rights, Humanitarianism, and Development, 1(1): 29-45. http://doi.org/10.1353/hum.2010.0005

Ahmed, Sara. 1999. “"She”ll Wake Up One of These Days and Find She's Turned into a Nigger': Passing Through Hybridity." Theory, Culture \& Society, 16(2): 87106.

Ahmed, Sara. 2017 Living a Feminsit Life. London: Duke University Press.

Ali, Mia. 2014. "Built to Carry Thirteen". In Chasing Misery: an anthology of essays by women in humanitarian responses, edited by Kelsey Hoppe, 51-60. CreateSpace Independent Publishing Platform.

Autesserre, Séverine. 2014. Peaceland: Conflict Resolution an the Everyday Politics of International Intervention. Cambridge: Cambridge University Press.

Baker, Catherine. 2016. "Writing About Embodiment as an Act of Translation." Critical Military Studies, 2(1-2), 120-124.

Bargués-Pedreny, Pol and Xavier Mathieu .2018. "Beyond Silence, Obstacle and Stigma: Revisiting the 'Problem' of Difference in Peacebuilding”, Journal of Intervention and Statebuilding 12 (3).

Bryant, Miranda. 2014. From New Orleans to South Sudan: How I Healed by Moving to a War-Torn Country. In Chasing Misery: an anthology of essays by women in humanitarian responses, edited by Kelsey Hoppe, 41-46. CreateSpace Independent Publishing Platform.

Case, S.-E. 1988. “Towards a Butch-Femme Aesthetic”. Discourses, 11(1), 55-73. 
Conboy, K., N. Medina and S. Stanbury. 1997. "Introduction”. In Writing on the Body: female embodiment and feminist theory, edited by K. Conboy, N. Medina and S. Stanbury, 1-12. New York, NY: Columbia University Press.

Dechaine, D. R. 2002. "Humanitarian Space and the Social Imaginary: Medecins Sans Frontieres/Doctors Without Borders and the Rhetoric of Global Community." Journal of Communication Inquiry, 26(4), 354-369. http://doi.org/10.1177/019685902236896

Donovan, K. P. 2015. "Infrastructuring Aid: Materializing Humanitarianism in Northern Kenya." Environment and Planning D: Society and Space, 33(4), 732-748. http://doi.org/10.1177/0263775815598107

Duffield, Mark. 2010. "Risk-Management and the Fortified Aid Compound: Everyday Life in Post-Interventionary Society”. Journal of Intervention and Statebuilding, $4(4), 453-474$.

Duffield, Mark. 2010). "The Liberal Way of Development and the DevelopmentSecurity Impasse: Exploring the Global Life-Chance Divide.” Security Dialogue, 41(1), 53-76. http://doi.org/10.1177/0967010609357042

Duffield, Mark. 2012. "Challenging Environments: Danger, Resilience and the Aid Industry." Security Dialogue, 43(5), 475-492.

Duncanson, Claire. 2009. "Forces for Good? Narratives of Military Masculinity in Peacekeeping Operations." International Feminist Journal of Politics, 11(1), 63-80. http://doi.org/10.1080/14616740802567808

Dyvik, Synne. L. 2016a. "Of Bats and Bodies: Methods for Reading and Writing Embodiment." Critical Military Studies, 2(1-2), 56-69.

Dyvik, Synne. L. 2016b. “"Valhalla Rising': Gender, Embodiment and Experience in Military Memoirs.” Security Dialogue, 47(2), 133-150. http://doi.org/10.1177/0967010615615730

Fast, Larissa. 2014. Aid in Danger: The Perils and Promise of Humanitarianism. Philadelphia, PA: University of Pennsylvania Press.

Feldacker, Caryl. 2014. "Home Is Where The Hard Is.” In Chasing Misery: an anthology of essays by women in humanitarian responses, edited by Kelsey Hoppe, 261-273. CreateSpace Independent Publishing Platform.

Gaanderse, Miranda. 2014. "Send In The Clown. In Chasing Misery: an anthology of essays by women in humanitarian responses, edited by Kelsey Hoppe, 135-148. CreateSpace Independent Publishing Platform. 
Givoni, M. 2011. "Beyond the Humanitarian/Political Divide: Witnessing and the Making of Humanitarian Ethics.” Journal of Human Rights, 10(1), 55-75.

Greenhalgh, Emilie J. 2014. “Answers Found In Harm’s Way: From Congo To Afghanistan." In Chasing Misery: an anthology of essays by women in humanitarian responses, editied by Kelsey Hoppe, 167-180. CreateSpace Independent Publishing Platform.

Hagon, Kirsten. 2014. “There Is No Rape In Darfur.” In Chasing Misery: an anthology of essays by women in humanitarian responses, edited by Kelsey Hoppe, 241254. CreateSpace Independent Publishing Platform.

Harari, Y. N. 2009. "Scholars, Eyewitnesses, and Flesh-Witnesses of War: A tense relationship." Partial Answers: Journal of Literature and the History of Ideas, 7(2), 213-228.

Heron, Barbara. 2007. Desire for Development: Whiteness, Gender and the Helping Imperitive. Ontario, Canada: Wilfrid Laurier University Press.

Hoppe, Kelsey, ed. 2014a. Chasing Misery: an anthology of essays by women in humanitarian responses. CreateSpace Independent Publishing Platform.

Hoppe, Kelsey. 2014b. "Preface”. In Chasing Misery: an anthology of essays by women in humanitarian responses, edited by Kelsey Hoppe, 11-15. CreateSpace Independent Publishing Platform.

Hoppe, Kelsey. 2014c. "Chasing Misery”. In Chasing Misery: an anthology of essays by women in humanitarian responses, edited by Kelsey Hoppe, 21-24. CreateSpace Independent Publishing Platform.

Hoppe, Kelsey. 2014e. “I Know What Fear Tastes Like.” In Chasing Misery: an anthology of essays by women in humanitarian responses, edited by Kelsey Hoppe, 210-220. CreateSpace Independent Publishing Platform.

Hubbard, Rachael. 2014. “The Great North Road.” In Chasing Misery: an anthology of essays by women in humanitarian responses, edited by Kelsey Hoppe, 151-158. CreateSpace Independent Publishing Platform.

Joseph, Jonathan. 2018. "Beyond Relationalism in Peacebuilding." Journal of Intervention and Statebuilding 12 (3).

Mac Ginty, Roger .2010. "Hybrid Peace: The Interaction Between Top-Down and Bottom-Up Peace.” Security Dialogue, 41(4), 391-412. http://doi.org/10.1177/0967010610374312 
Mac Ginty, Roger. 2017. A Material Turn in International Relations: The 4x4, Intervention and Resistance. Review of International Studies, Online, 1-20. http://doi.org/10.1017/S0260210517000146

Mac Ginty, Roger. And Oliver Richmond. 2015. "The Fallacy of Constructing Hybrid Political Orders: A Reappraisal of the Hybrid Turn in Peacebuilding." International Peacekeeping, 3312(November), 1-21. http://doi.org/10.1080/13533312.2015.1099440

McLeod, Laura. 2015. "A Feminist Approach to Hybridity: Understanding Local and International Interactions in Producing Post-conflict Gender Security.” Journal of Intervention and Statebuilding 9 (1): 48-69. http://dx.doi.org/10.1080/17502977.2014.980112

Martin de Almagro, Maria. 2018. "Hybrid Clubs: A Feminist Approach to Peacebuilding in the Democratic Republic of Congo" Journal of Intervention and Statebuilding 12 (3).

Martin de Almagro, Maria. 2017. "Producing Participants: Gender, Race, Class, and Women, Peace and Security." Global Society Online. https://doi.org/10.1080/13600826.2017.1380610

O’Donoghue, Lucy. 2014. "Relationships: At the heart of, well, everything.” In Chasing Misery: an anthology of essays by women in humanitarian responses, edited by Kelsey Hoppe, pp. 79-85. CreateSpace Independent Publishing Platform.

O'Heir, Tracy. 2014. "Beating the Odds." In Chasing Misery: an anthology of essays by women in humanitarian responses, edited by Kelsey Hoppe, 71-78. CreateSpace Independent Publishing Platform.

Older, Malka. 2014. “Accepting Thanks.” In Chasing Misery: an anthology of essays by women in humanitarian responses, edited by Kelsey Hoppe, 295-301. CreateSpace Independent Publishing Platform.

Partis Jennings, Hannah. 2017. “The (In)Security of Gender in Afghanistan's peacebuilding project: Hybridity and Affect.” International Feminist Journal of Politics 19(4): 411-425. https://doi.org/10.1080/14616742.2017.1279418

Pratt, Mary Louise. 2008. Imperial Eyes: Travel Writing and Transculturation. $2^{\text {nd }}$ ed. Abingdon: Routledge.

Philips, Melissa. 2014. "Real Women in Aid Work: Must We Be Either Angelina Jolie or Mother Theresa? In Chasing Misery: an anthology of essays by women in 
humanitarian responses, edited by Kelsey Hoppe, 25-29). CreateSpace

Independent Publishing Platform.

Randazzo, E. 2016. "The Paradoxes Of The "Everyday": Scrutinising The Local Turn

In Peace Building". Third World Quarterly, 6597(March), 1-20.

http://doi.org/10.1080/01436597.2015.1120154

Redfield, Peter. 2016. "Fluid Technologies: The Bush Pump, the LifeStraw ${ }^{\circledR}$ and

Microworlds of Humanitarian Design.” Social Studies of Science, 46(2), 159-

183. http://doi.org/10.1177/0306312715620061

Repo, J., and R. Yrjölä. 2011. "The Gender Politics of Celebrity Humanitarianism in

Africa.” International Feminist Journal of Politics, 13(1), 44-62.

http://doi.org/10.1080/14616742.2011.534661

Richmond, Oliver, Stefanie Kappler and Annika Björkdahl. 2015. "The "Field" in the

Age of Intervention: Power, Legitimacy, and Authority Versus the "Local."”

Millennium - Journal of International Studies, 44(1), 23-44.

http://doi.org/10.1177/0305829815594871

Rieff, David. 2002. A Bed For The Night: Humanitarianism In Crisis. London: Vintage.

Roberson, Steph. 2014. "Falling Down.” In Chasing Misery: an anthology of essays by

women in humanitarian responses, edited by Kelsey Hoppe, 61-69.

CreateSpace Independent Publishing Platform.

Robinson, A. 1994. "It Takes One to Know One: Passing and Communities of Common Interest.” Critical Inquiry, 20(4), 715-736.

Romano, Roberta. 2014. “The Subtle Thread." In Chasing Misery: an anthology of essays by women in humanitarian responses, edited by Kelsey Hoppe, 199-207. CreateSpace Independent Publishing Platform.

Roth, Silke. 2014. “Aid Work as Edgework - Voluntary Risk-Taking and Security in Humanitarian Assistance, Development and Human Rights Work.” Journal of Risk Research, 18(2), 139-155. http://doi.org/10.1080/13669877.2013.875934

Scott-Smith, Tom. 2013. "The Fetishism of Humanitarian Objects and the Management of Malnutrition in Emergencies. Third World Quarterly, 34(5), 913-928.

http://doi.org/10.1080/01436597.2013.800749

Seeger, Helen. 2014. "The Field: The Ever Receeding Vanishing Point.” In Chasing Misery: an anthology of essays by women in humanitarian responses, edited by Kelsey Hoppe, 31-35. CreateSpace Independent Publishing Platform. 
Sheehan, Carman. 2014. "No Place." In Chasing Misery: an anthology of essays by women in humanitarian responses, edited by Kelsey Hoppe, 226-240. CreateSpace Independent Publishing Platform.

Smirl, Lisa. 2008. "Building The Other, Constructing Ourselves: Spatial Dimensions of International Humanitarian Response. International Political Sociology, 2(3), 236-253.

Smirl, Lisa. 2012. “The State We Are(n't) In: Liminal Subjectivity in Aid Worker Biographies." In Statebuilding and State Formation: the political sociology of intervention, edited by Berit Bliessman de Guevara, 230-245. London: Routledge.

Smirl, Lisa. 2015. Spaces of Aid: How Cars, Compounds and Hotels Shape Humanitarianism. London: Zed Books.

Smirl, Lisa. 2016. “"Not Welcome at the Holiday Inn”: How a Sarajevan Hotel Influenced Geo-politics." Journal of Intervention and Statebuilding, 2977(February), 1-24. http://doi.org/10.1080/17502977.2015.1137398

Sylvester, Christine. 2013. War as Experience: contributions from international relations and feminist analysis. Abingdon: Routledge.

Ticktin, Miriam. 2011. "The gendered human of humanitarianism: Medicalising and politicising sexual violence." Gender and History, 23(2), 250-265. http://doi.org/10.1111/j.1468-0424.2011.01637.x

Townley, Ruth. 2014. "Holding Their Stories." In Chasing Misery: an anthology of essays by women in humanitarian responses, edited by Kelsey Hoppe, 127-134. CreateSpace Independent Publishing Platform.

Welland, Julia. 2013. "Militarised Violences, Basic Training, and The Myths of Asexuality and Discipline.” Review of International Studies 39(4), 881-902. http://doi.org/10.1017/S0260210512000605

Welland, Julia. 2015. "Liberal Warriors and the Violent Colonial Logics of "Partnering and Advising."' International Feminist Journal of Politics, 17(2): 289-307 http://doi.org/10.1080/14616742.2014.890775

Wilcox, Lauren. B. (2015). Bodies of Violence: Theorizing Embodied Subjects in International Relations. Oxford: Oxford University Press.

Woronka, Kati. 2014. “Of Pastries, Loss, and Pride.” In Chasing Misery: an anthology of essays by women in humanitarian responses, edited by Kelsey Hoppe, 115122. CreateSpace Independent Publishing Platform. 
${ }^{\text {i }}$ The book also features photographic contributions but these have not been included in this analysis as they are not examples of aid workers narrating their own experiences. The photographs are not of the contributor women themselves but rather of those they are 'aiding'.

ii I want to thank Xavier Mathieu for his extremely helpful suggestion to explore this literature.

iii Kelsey Hoppe contribute three essays, including the introduction and Helen Seeger contributes two essays to the collection.

iv Though not all authors chose to share the information about their nationality, of those that do, most are from the UK, Europe, Australia, New Zealand and the US.

${ }^{\vee}$ Though here the clothes are a metaphor, in this issue, Maria Martin de Almagro explores they ways that clothes are used in performances of hybrid peacebuilding identities (see also, Partis-Jennings, 2017, 419).

${ }^{\text {vi }}$ For more on hauntings and masculinities, see Welland, 2013. 


\title{
Embodying difference: reading gender in women's memoirs of humanitarianism
}

\author{
Róisín Read ${ }^{\text {a* }}$ \\ ${ }^{a}$ Humanitarian and Conflict Response Institute, University of Manchester, Manchester, \\ Greater Manchester
}

*corresponding author roisin.read@manchester.ac.uk Humanitarian and Conflict Response Institute University of Manchester, Ellen Wilkinson Building C2.12, Oxford Road, Manchester M13 9PL.

Róisín Read is a Lecturer in Peace and Conflict Studies at the Humanitarian and Conflict Response Institute at the University of Manchester. Her research explores the research explores the politics of international interventions in conflict, with a focus on the dynamics of knowledge production and representation. Her recent research focuses on gender and race in narratives of the humanitarian encounter, as told through memoir and fiction.

Acknowledgements: I would like to thank the editors of this special issue, Pol Bargués-Pedreny and Xavier Mathieu, for the opportunity to be part of such a rewarding collaboration, as well as the other contibuotrs to the workshop from which this special issue came, especially Nicolas Lemay-Hébert. I thank the two anonymous reviewers for their helpful and generous suggestions, in particular the recommendation to engage with the work of Hannah Partis-Jennings, whom I would also like thank. The idea for this piece came from my participation in a workshop organised Laura Mcleod and Maria O'Rielly in 2016 on feminist interventions in critical peacebuilding, I thank them for the inspiration. 


\title{
Embodying difference: reading gender in women's memoirs of humanitarianism
}

\author{
Róisín Read ${ }^{\mathrm{a} *}$ \\ ${ }^{a}$ Humanitarian and Conflict Response Institute, University of Manchester, Manchester, \\ Greater Manchester \\ *corresponding author roisin.read@ manchester.ac.uk Humanitarian and Conflict \\ Response Institute University of Manchester, Ellen Wilkinson Building C2.12, Oxford \\ Road, Manchester M13 9PL.
}

Róisín Read is a Lecturer in Peace and Conflict Studies at the Humanitarian and Conflict Response Institute at the University of Manchester. Her research explores the research explores the politics of international interventions in conflict, with a focus on the dynamics of knowledge production and representation. Her recent research focuses on gender and race in narratives of the humanitarian encounter, as told through memoir and fiction. 
This paper seeks to explore what we can learn about embodied difference in humanitarianism and peacebuilding by taking seriously women's memoirs as a form of 'flesh witnessing' (Harari 2009). It argues that the essays in Chasing Misery (Hoppe 2014a) are simultaneously claims to the authority of 'The Field' but also reveal the sense to which the women feel they are only 'passing' as aid workers. I note three themes of difference, beginning with the construction of 'The Field' as a site of embodied authority and the ways in which the women's essays reinforce and trouble this. Secondly, the writers' feeling different from, and separate to, the people they work with and for. Finally, embodied gender presented with reference to imagined 'real' aid worker.

Keywords: gender; difference; passing; embodiment; memoir, aid worker

\section{Introduction}

Humanity has long been cited as humanitarians' main constituency, yet, despite the obviously gendered nature of the humanity being discussed, the humanitarian sector (including academics) has been slow to make gender a central category of analysis. Gender has been a central aspect of humanitarian programming without key questions being asked about how gendered power relations shape the sector more broadly. As Miriam Ticktin notes $(2011,250)$, humanitarian discussions of humanity raise a central paradox of feminism, that 'one must emphasise one's difference (as women) in order to claim one's sameness (as equal human beings)'. This manifests in relation to 'debates about whether to include women as equal subjects/objects of humanitarian aid... or whether to single them out as different in order for them to receive critical attention and care' (ibid). Gender is a key category of difference in humanitarianism and peacebuilding but has tended to be overlooked in favour of discussions about the differences between the local and international (for exceoptions see Partis-Jennings, 
2017; McLeod, 2017; and Martin de Almagro, this issue). In this paper, I seek to explore embodied accounts of difference in humanitarianism by considering Chasing Misery (Hoppe 2014a), an anthology of essays by female aid workers. I claim that we can learn about practices of humanitarianism and peacebuilding by taking these accounts seriously, not as objective truth, but as examples of 'flesh witnessing' (Harari, 2009).

As Duncanson notes $(2013,57)$ in relation to soldiers, there is something 'particularly revealing about identity' in memoirs which are 'their story as they want to tell it'. They can tell us about 'which embodied experiences become important', or more simple, 'whose bodies count' (Dyvik 2016a, 59). However, they are not just revealing about personal identities but also collective identity, these memoirs shape and are shaped by broader social imaginaries. imaginaries - following Lennon $(2015,1)$, the 'affectively laden patterns/images/forms, by means of which we experience the world, other people and ourselves' - which affect not only how aid workers and wider publics think about humanitarian aid, but also how they think about the spaces in which humanitarian aid is deployed and the people who receive it.

Humanitarians, especially in conflict-affected areas, increasingly serve as sources of knowledge about the areas they work and people they work with, as such it is important to critically interrogate their experiences and knowledge. How female aid workers narrate their experiences of the spaces of humanitarianism can offer important insights into the construction and maintenance of a distinctly humanitarian social imaginary. It also highlights the complex and intersecting hierarchies of gender, race, class, nationality and age which are deeply embedded in humanitarian practices. The 22 stories in the Chasing Misery (Hoppe 2014a) collection ${ }^{\mathrm{i}}$ frequently collapse public/private, work/life binaries in different ways. They address complex emotional 
and fundamentally sensorial experiences, often viscerally. Difference appears in the stories, in relation to colleagues, recipients of aid, parties to conflict and friends and family 'back home', but it is always embodied. This embodiment matters as there is always 'a tension between women's lived bodily experiences and the cultural meanings inscribed on the female body that always mediate those experiences' (Conboy, Medina and Stanbury 1997, 1).

In order to explore this tension, I read these stories through a double lens of 'flesh witnessing' and 'passing'. ii In doing so, I address 'difference' in peacebuilding and humanitarianism as a gendered relation of power, highlighting three of the ways existing norms of what it means to be an aid worker produce the women as different such that they 'have to pass as what you are assumed not to be' (Ahmed 2017, 115). As such, the women must perform their identity as aid workers - to try to pass - because the legitimacy of their claim to the identity is in question (120). In drawing attention to the ways in which the identities are performed, it is possible to see how the norms which establish difference are both reinforced and contested. I will begin by arguing that the women's narrations of their experiences are claims to the authority of 'The Field'. Following this, I will highlight they ways in which the writers produce themselves as different to, and separated from, both the populations they are there to assist and their own communities 'back home'. Finally, I will show how the essays also reveal the sense many of the women experience of 'being inadequate to the identity' (Ahmed $1999,96)$ of aid worker. In taking the essays of women in aid work as a starting point I hope highlight the ways in which difference is always embodied and is imbued with meanings, whether somebody realises it, or not. Before outlining the approach I take to reading the women's essays, I will briefly introduce the anthology, Chasing Misery (Hoppe, 2014a). 


\section{Chasing Misery}

Published in 2014, Chasing Misery: an anthology of essays by women in humanitarian responses is edited by a team, led by Kelsey Hoppe, an aid worker with both humanitarian and development experience in a range of countries. She states that she developed the idea for the anthology 'as a way to give a platform to women's perspectives and voices in the work they do as well as to help people better understand what humanitarian aid is' (chasingmisery.net, n.d). The book has 24 essays written by 21 different women ${ }^{\mathrm{iii}}$, including a preface by Kelsey Hoppe (2014b). The women come from a variety of different backgrounds ${ }^{\mathrm{iv}}$ and have worked in humanitarianism in different roles and capacities.

The editor, Kelsey Hoppe, is explicit in her belief that women have distinct insights to offer; 'women's voices, perspectives and narratives on aid work are unique and deserve their own space'. She suggests this is in part because of their ability 'to explore the greys, the 'inbetweenness', to reflect on the questions about being human' (2014b, 12). The book starts from the assumption that women have a different perspective on the world, different, that is, presumably, to men. Feminism has long been interested in situated knowledges (Haraway 1988), and the book poses interesting questions about the liminality of women in humanitarianism and peacebuilding (for more on the liminality of women in peacebuilding see, Partis-Jennings 2017, 418). For endeavours which claim gender as a central policy and programming expertise, surprisingly little attention has been paid to the ways in which their everyday humanitarian practices are gendered, given the feminist underpinnings of the 'local' and 'experiential' turns, this oversight seems even more stark. 


\section{Difference, embodiment and passing}

Feminist approaches to international relations have, in recent years, highlighted the need for bodies to be brought inside 'the frame of international relations' (Wilcox 2015). This literature has tended to focus on the ways in which war needs to be understood as an embodied experience by 'centralizing people's experiences' (Dyvik 2016a, 56). I argue that extending this lens to peacebuilding and humanitarianism is a key move, as these activities are deeply embedded in conflict and, thus, are a key site of investigation for more fully understanding the lived experiences of conflicts and their aftermaths. Though there has been an experiential turn in the study of peacebuilding, much of this literature leaves the feminist origins of the move to the 'everyday' implicit and the analyses remain at a level of abstract from specific lived experiences which precludes an embodied analysis, though the work of Laura McLeod (2015); Hannah Partis-Jennings (2017) and Maria Martin de Almagro (2017 and this issue) are exceptions. As Christine Sylvester notes (2013, 5, emphasis in original), our experiences of war, and I would argue interventions in war, are 'experienced through the body', so we must look at the body as a unit of analysis. International aid workers in conflict settings have interesting and distinct experiences of war; they occupy a strange liminal position, in the conflict, but ostensibly not part of it. At risk, but also secured from violence. The lived experiences of these tensions can perhaps offer us insights into the broader dynamics of conflicts and the interventions which seek to end or ameliorate them.

Just as Duncanson (2009), Welland (2015) and Dyvick (2016a, 2016b) have looked to military memoirs to study the gendered performances at the heart of recent and contemporary conflicts, I argue that humanitarian memoirs can help us to explore the embodied racialised and gendered experiences of aid in conflict. I do not suggest that these memoirs can be seen unproblematically as 'true accounts', rather, following 
Duncanson $(2009,57)$, there is 'something particularly revealing about identity' in pervasive belief that there is something about the experience of being in these conflict spaces that is impossible to convey to those who have not experienced it; "it is experienced by those who practice it as a bracketed space, one in which only a few have access to, at once a manifestation of life at its most real and its direct counterpart' (Dyvik 2016, 57). Yet, paradoxically, it is an elusive or illusory endeavour, as they will never fully be able to communicate the 'reality' of the experience.

As Catherine Baker $(2016,120)$ suggests, writing about embodiment is necessarily an act of both compression and translation, 'reducing the sensory complexity of someone else's physical experience, or even one's own, into written language that someone else will understand through sight or sound'. Yuval Noah Harari (2009) offers a way of thinking about this problematic through the notion of 'flesh witnessing', a phrase drawn from the observation of a French soldier from the First World War that one "who has not understood with his flesh cannot talk to you about it [the experience of war]' (as quoted in Harari 2009, 215, emphasis in source).

The notion of flesh witnessing is especially intriguing in thinking about the humanitarian field as the idea of 'witnessing' and 'speaking out' has a controversial history in humanitarian aid interventions (for example, Givoni 2011). In contrasting flesh witnessing to eye witnessing, Harari $(2009,217)$ notes the different kind of authority associated with each. With eye witnessing, authority comes from the notion that you can observe 'facts' which can be verified. This relies on a mastery over a field of information that humanitarians rarely have more than partial access to. Flesh witnessing, on the other hand, offers a more 'novel authority... which is based not on the observation of facts but on having undergone personal experience'. Harari notes that 
flesh witness accounts seem to be interested in conveying experiences but because they do not believe these experiences can be conveyed to those who have not had the same experiences, 'by definition, they cannot succeed in this' (221). Instead, 'flesh witness narratives are mainly an exercise in authority’ (222). As Dyvik notes of military memoirs, they seem to convey 'you don't know what it's like', while attempting to tell the reader any way (Dyvik, 2016a: 58), as such, what they establish is the authority of the speaker.

Humanitarian memoirs are not only important for what they reveal about specific humanitarian experiences, but also for how they frame a broader social imaginary of what humanitarianism is. As Dyvik notes (2016a, 58), military memoirs are more than individual stories, 'these texts participate in the writing of war. They help frame what we think war is'. Similarly, humanitarian memoirs participate in the writing of humanitarianism and help us from what we think humanitarianism is. At the beginning of 2000s, David Reiff $(2002,87)$ critiqued the portrayal of humanitarianism which relied on a 'familiar morality play of victims in need and aid workers who stand ready to help if their passage can be secured and their safety maintained'. This remains a common (and deeply gendered) trope in humanitarian imagery.

Michel Agier $(2010,32)$ notes, '[t]he humanitarian world is based upon the fiction of humanity as an identity'. This identity draws legitimacy from a mythologised humanitarian history and legacy in which 'humanitarian exceptionalism' is entrenched in a particular reading of international humanitarian law (Fast 2014). However, as Ticktin (2011) notes in relation to humanitarian efforts to address sexual violence, the human upon which humanitarians have built their identity is gendered and racialised. She argues that the expansion of the humanitarian mission to include gender-based violence 'has inadvertently opened up space for confrontation with politically 
significant forms of difference and inequality' (262). I argue that humanitarian memoirs, as a form of 'flesh witnessing' (Harari 2008), offer an interesting way of thinking about difference as embodied.

When difference appears in discussions of peacebuilding, the most common difference cited is between the local and the international, as Lisa Smirl (2012) explored in relation to liminality in humanitarian memoirs. This binary is so embedded within peacebuilding literature that a subfield of literature has emerged to explore how it can be broken down through notions of hybridity (see for example, Mac Ginty 2010; Mac Ginty \& Richmond 2015). Concurrently, in discussions of aid worker security particularly, there has been recognition that there currently exists a 'humanitarian exceptionalism' (Fast 2014), whereby the 'expat' aid worker's status is rendered as something distinct from military or civilian; reinforced by their distinct security practices (Duffield 2010). The 'local turn' in peacebuilding has sought to challenge the dominance of international knowledge in both academic literature and practices of peacebuilding, yet in doing so has reinforced the distinction between local and international (Randazzo 2016).

As Bargués-Pedreny and Mathieu (this issue) note, within this hybridity literature;

differences are reified and essentialised as inescapable, but also, and perhaps more importantly, difference is linked to stigma (as a deviance from the 'normal' that is reproduced by the frames used to identify it)... emphasising difference (even as something to be celebrated, a space to cultivate bottom-up peace initiatives) does not remove the stigma attached to it insofar as the 'norm' is not questioned nor displaced.

Drawing on a different reading of hybridity in the work of Sara Ahmed (1999, 88, emphasis added), she talks of hybridization in the context of racial identity, as the 
rejection of the notion that two racial identities 'can be distinguishable in space and time: hybridization as the very temporality of passing through and between identity itself without origin or arrival'. Bargués-Pedreny and Mathieu (this issue), following Minow, suggest that we need to pay greater attention to the power relations which produce differences which then are presented as already existing, they call for us to see 'to how differences lie between people and not within them'. Passing offers a useful way of thinking about difference in this way, as it involves social differentiation which looks at structural rather than essential difference and invites the 're-opening or restaging of a fractured history of identifications' (Ahmed 1999, 93).

Building on Ahmed's $(1999,93)$ consideration of passing - which explores passing in relation to racial and sexual identity - it is only 'ambiguous exceptional bodies' whose difference is remarked upon. Aid workers have, in discourses of peacebuilding, been presented as exceptional 'international' bodies, in contrast to an often homogenised 'local'. Yet, this exceptional category - of international aid worker has also tended to be treated as homogenous. The implication is that their status as 'aid worker' overwrites all other kinds of difference, for example gender, race, class, nationality and religion. This is partly a consequence of the tendency to study humanitarianism as a disembodied organisational practice.

Partis-Jennings' (2017: 418) discussion of the 'third sex' - 'hybrid bodies, which were marked as both female and foreign, both vulnerable and powerful' highlights how a focus on gender and embodied affective experiences troubles the notion that 'international' actors can be seen as a collective category. In this paper, insisting on humanitarianism as an embodied practice allows for the differences between those international aid workers to be interrogated, and the implications of the power relations which produce these differences to be questioned. While the focus here 
is on embodied difference as narrated by the 'flesh witness' accounts, there is also a need to consider, as Joseph (this issue, ?) warns, 'the underlying social structures that, in a sense, make experience and performance possible as well as imposing constraints on it'.

As this section has outlined, the notion of flesh witnessing offers a way of reading the accounts of the women in the anthology as establishing their authority to speak about humanitarianism. However, at the same time as conveying the authority of 'The Field', the essays can also be read through the lens of passing. Just as Ahmed (1999) suggests that passing is both an 'act of moving through space' and 'a set of cultural and embodied practices', in the essays, the women writing are 'passing through' the places they write about as well as 'passing as' aid workers by embodying as set of practices which encourage the reader to view them as such. Likewise, just as they do not come to inhabit the places they pass through, as we will see, they also do not come to fully inhabit the identity of 'aid worker'. Rather, their 'passing' as aid workers is troubled by their identity as women.

The stories seem to serve to re-enforce the identity politics of aid. This is a politics, as Melissa Philips's $(2014,27)$ essay 'Real Women in Aid Work: Must we Be Either Angelina Jolie or Mother Theresa?' states, in which there are only a limited number of dominant interpretive schema for aid workers - either saints and saviours or 'missionary, mad, or misfit'. In these schema, the common assumption is that the aid worker is male. The stories then occupy an uneasy position, conveying the sense in which the women experience exclusion from the aid worker identity while also speaking with the authority granted them by their 'flesh witnessing' as aid workers. It is with the notion of these accounts as conveying authority that my analysis of the essays from Chasing Misery will begin. 


\section{The authority of 'The Field'}

As the previous sections have highlighted, thinking about the women's essays through the lens of flesh witnessing allows them to be viewed as accounts which establish the authority of the teller to speak about the humanitarian experience. One of the key ways this manifests in the story is through the reference to 'The Field'. As Helen Seeger (2014, 31) observes in her essay 'The Field: The Ever Receeding Vanishing Point', there is an authenticity that comes through discomfort in the aid worker sector; your recognition by your peers is 'directly proportional to how authentically grubby, sweaty, sunburnt and sleep deprived her or she is'. This hierarchy operates, Seeger adds, through an aid worker's 'proximity to a mythical place called 'The Field'. In the essay, Seeger sardonically charts her elusive and on-going search for a place called 'The Field' across deployments and projects which always seems to be 'somewhere else, just down the road (31).

This view echoes the work of Lisa Smirl $(2012,237)$ who refers to 'The Field' as a liminal space, in which 'spaces of work and play blend into one', totally collapsing any public/private distinction. As Richmond, Kappler and Björkdahl $(2015,24)$ have argued, the field is a label which is used extensively in peacebuilding, development and research to 'label a discursive and geographical space different from their own'. This difference is essential to the construction of the discursive frame of the field, Richmond, Kappler and Björkdahl suggest that the most obvious link is agrarian, fields which are farmed by peasants (25), but I suggest, in humanitarian and peacebuilding settings, the uses of this phrase owes more to military terminology, as it is usually accompanied by the terminology, security protocols and fashion, as will be discussed later, of 'deployment'. 
The imagined space of 'The Field' is, then, the site of authentic flesh witnessing, and just as this can never truly convey the experience of aid, the frame of 'The Field' discursively replicates this distance and Othering, as it is a space which cannot be truly reached. Borrowing Seeger's words; 'The field is in [insert dustier place], where Aid Workers are Aid Workers' (2014, 32). Sheehan explicitly refers to Darfur, her 'Field', as 'No Place' (2014). 'The Field' is a 'bracketed space' of the kind Dyvik notes (2016a, 57), inaccessible and filled with life at its most real due to the risk of death. It is especially inaccessible to international aid workers, as Seeger suggests $(2014,35)$, due to security concerns. However, this only seems to make it a more desirable location; supporting Roth's analysis $(2014,140)$ of aid as voluntary risk-taking or 'work that requires negotiating the edge'.

Other essays in the collection comment on features of 'The Field', and one of the most common and recurring features is the $4 \times 4$ or sports utility vehicle (SUV). As Lisa Smirl (2008; 2015; 2016), Mark Duffield (2010; 2012) and others (Abdelnour \& Saeed 2014; Autesserre 2014; Donovan 2015; Redfield 2016; Scott-Smith 2013) have highlighted, the physical spaces and material practices of aid work in recent years have functioned to create further distance between international aid workers and the populations of the countries they are resident in. The SUV is the main mode of accessing the field but it also represents the distance from it. As Mia Ali’s $(2014,52)$ essay, 'Built to Carry Thirteen', powerfully puts it 'I'm too busy helping beneficiaries to help the people by the side of the road'. She highlights the distancing effect of being in the $4 x 4$, separated from (both physically and emotionally), those populations they claim to assist.

Research by Donovan $(2015,740)$ also addresses the $4 \times 4$ suggesting that, 'the functionality of the $4 \times 4$ allows those with access to move about more fluidly' (to pass 
through), but it also renders the aid worker 'as more secure - even more dangerous - as the vehicle hurtles through the bush'. While some of the essays draw attention to the relative security and mobility the $4 x 4$ s provide the passenger - Tracy O'Heir's (2014, 73-74) 'Beating The Odds' notes the absence of safety felt when the promised NGO $4 \times 4$ does not arrive to pick her up - in the main, the experiences of the women in relation to the security and danger of the $4 \times 4$ are much more ambiguous, troubling the dominant narrative of 'bunkerisation' (see for example, Duffield 2010).

Rachael Hubbard's $(2014,152)$ essay 'The Great North Road', flips this idea of the vehicle as a site of security as she recounts 'the day I almost died on the Great North Road'. The Land Rover in her story is a space of 'torture' (151), as she is loaded into the, prone to breaking down, vehicle feverish with malaria. In this moment, she questions the profession: 'Is this what it meant to serve mankind? Watching children starve, watching babies die, fever, exhaustion, and fighting to breathe?' (157) but ultimately concludes that the experience has 'much to offer and much to teach' (159). Ruth Townley $(2014,127)$ begins her essay, 'Holding Their Stories', in a Toyota Hilux 'hurtling down a claustrophobic dirt road' with her seat belt unbuckled as her driver tells her the extra time it takes to 'takes to unbuckle can make the difference between life and death', the present danger of ambush clear in remains of a previous unlucky vehicle from her NGO they pass.

Mac Ginty (2017) has explored the value of the $4 x 4$ s to the conflict in Darfur, and Kelsey Hoppe (2014e) picks up this theme in her essay 'I Know What Fear Tastes Like'. She recounts the 'Gereida incident' from her time in Darfur. The incident sticks in her mind because of the 'brutality against NGOs themselves' (210), a night in which a rebel group attacked an NGO compound, stole vehicles, communications equipment and attacked Sudansese staff (211). She recalls another 'incident' in which a driver is 
killed, staff missing and 'vehicles had been torched' (213-214), again, countering the prevalent discourse that the ever present $4 \times 4$ is a site of security for aid workers, these women's flesh-witnessing challenges the unproblematic notion that for those international actors involved in intervention; 'exclusive transport links into an archipelago of protected international space' (Duffield 2010, 71).

Carmen Sheehan (2014) in her essay 'No Place', also about Darfur, draws attention to another danger experienced in relation to the $4 \times 4$, that of the road block/check point which also appears in Kirsten Hagon's essay, “There Is No Rape In Darfur" (2014). Sheehan describes being stopped at a check point shortly before curfew, her inner monologue, courtesy of her security training, highlights a very specific fear from the previous week's security briefing of an attempted rape of a female driver at a checkpoint after dark (234-235). In the essay, Sheenan collapses mind/body and internal/external distinction as the reader gets the physical and mental manifestation of her fear simultaneously, alongside the description of the interaction at the check point: 'Willing the motor not to die, I backed gently out into the road and glanced in the rear view mirror. If the firing squad in the road kept it together I would be free' (237). This highlights the way gender impacts feelings of security, a key theme of Partis-Jennings' (2017) work on gendered (in)security in Afghanistan.

The distance which the women report feeling in 'The Field' is not simply physical, represented by the separation of the $4 \times 4$, or in the material difference in the lives of international aid workers. It is also an emotional distance, as Lucy O’Donoghue's (2014) essay 'Relationships: At the heart of, well, everything' makes apparent. She compares the 'years of a transitory lifestyle' of the international aid worker to "the relative stability that our local staff often have through their communities and families' (84). Again we see that these women are simply passing through, their 
difference allows them this privilege which also creates distance. She highlights this 'vacuum' as a 'lack' on the part of international aid workers (85). Interestingly, O’Donoghue (85) suggests a need for the building of relationships to reduce the 'gaping chasm of otherness found between expatriate and national staff', through a recognition of the embodied humanness of the Other; 'being human, recognising our need to give ourselves in relationship and in community.' This is not a vision of an idealised local community, but a recognition that local staff 'rarely got the opportunity to compartmentalise their lives'. In contrast, in the bracketed, liminal space of 'The Field', international aid workers are 'thoroughly unmoored' (80) from not only the communities they are present to assist but also from their own communities back home, and in some cases, their own emotions.

The nomadic lifestyle of the international aid worker is a key narrative through which difference is produced. O'Donoghue notes how 'bizarre' it must appear to local staff that 'we, the expatriates, would forfeit out own natural environment and longstanding relationships to insert ourselves, usefully or otherwise, into their relatively insecure world' (81, emphasis added). Through the notion of the 'natural' environment being other than the field, the difference of the international aid worker is reproduced. Yet, common to many humanitarian memoirs is the trope of alienation from 'home', both while in the field and especially once returning to 'normal' life.

This paradox at once produces 'The Field' as exceptional but also as real in a way that ordinary life is not. It is a place people need to return to in order to feel fully alive; as Emilie J. Greenhalgh $(2014,178)$ puts it in her essay 'Answers Found In Harm's Way: From Congo to Afghanistan'; ‘

I had not been able to find a balance between the fascination of the crisis, the romance of the humanitarian work, and the blatant desire of a twenty-something 
woman to have fun and not simply revel in chasing the misery the world dishes out every goddamn day'.

'Chasing Misery' is also the title of another of Kelsey Hoppe's essays and it picks up this theme, the desire to experience, as much as possible, the thrill and romance of the field.

The sacrificing of comfort and relationships, which will be explored further shortly, in pursuit of this nebulous idea of authenticity, of 'real' aid work comes up in Hoppe's (2014c, 21) essay, as she notes:

We parade through life dressed in immortality. Traipsing around places where it is likely that we will be shot or drowned or kidnapped or beheaded by people who believe things a little too much. Trying our immortality on for size, like new clothes, seeing if it fits. It never does. Immortality never fits anyone.

Again, there is a recurring sense of the illusiveness of the authenticity of experience which is being sought. The metaphor of clothes ${ }^{v}$ and their fit resonates with Ahmed's $(2017,125)$ comments on institutional passing, that 'an institution is like an old garment. It acquires the shape of those who tend to wear it; it becomes easier to wear if you have that shape'. Even as their experiences of the field allow them to speak with its authority, there is a sense of alienation from the identity they are trying (and failing) to inhabit. It does not quite fit and they do not quite fit in it; 'The Field' is always elsewhere, but this only serves to make the search for it more insistent. Thinking about this through the lens of passing highlights the ways in which the women in their essays simultaneously recognise the problematic authority of 'The Field' and also reproduce it, as Robinson $(1994,735)$ suggests, '[t]he limited subversion of the pass always requires the terms of the system be intact'.

This section has sought to explore the locus of authentic experience, as told in the essays of Chasing Misery (Hoppe 2014a). As a bracketed space to which others do 
not have access, 'The Field' serves as a space of authenticity of which only flesh witnesses can speak. However, the narratives offered in the collection both reproduce and trouble this notion, highlighting the ways in which this space is always out of reach. Indeed, this elusive quality is no doubt part of its appeal. They also highlighted the 'inbetweeness' of occupying this space 'unmoored' (O'Donoghue 2014, 80; Older 2014,300 ) from relationships which give meaning and thus fostering a search for meaning through 'chasing misery'. The next section will pick up on this notion of 'inbetweeness' and explore the ways in which race and gender appear in the women's narratives and can reinforce and trouble notions of 'humanitarian exceptionalism' (Fast 2014).

\section{'Muzungus', gender and humanitarian exceptionalism}

In the previous section, I noted that the limited subversion of the essays in the book challenges the dominant humanitarian narratives, but ultimately ends up also reproducing them. The essays in the book challenge, reflect on and reproduce the humanitarian system. Humanitarian memoirs are not only important for what they reveal about the humanitarian experience and imaginary, but also for how they frame for a broader social imaginary what humanitarianism is.

In her essay, 'Of Pastries, Loss and Pride', Kati Woronka (2014) notes the divide between international aid workers and 'Beneficiaries' the optimistic name 'we aid workers call the people we help' (Seeger 2014, 32). Woronka, describes this feeling of divide, noting in particular the generalising names that come to define them in different places; 'I felt a terrible divide between expatriates, including myself, and the people we were there to serve. There was always a name for us: Malae in East Timor, Blancs in Haiti, Khawaja in Darfur' (2014, 118-119). Miranda Gaanderse's (2014, 144) essay 'Send In The Clown' notes, of her experience working with Unaccompanied 
Minors in Uganda, the "personal victory that they now call by name rather than 'Muzungu',

Yet, some of the authors also fall into this trap, referring to themselves as 'expatriates' (see, O’Donoghue 2014; Woronka 2014) or 'expats' (see, Feldacker 2014; Greenhalgh 2014), explicitly placing themselves into an 'us' group which is contrasted with the 'them' of the intervention zone. As Woronka $(2014,119)$ suggests, this grouping seemed 'somehow inevitable: to the people we came to serve, we weren't individuals. We were foreign objects. And, no doubt, our hosts figured we felt the same about them. Maybe we did'. As Smirl has argued $(2012,230)$, it is in the everyday practices of 'The Field' and 'their accompanying spaces (the offices, compounds, workshops, projects) that the categories of local and international are (re)produced despite rhetorical commitments to move beyond them'.

This separation, as mentioned above, operates on more than one level, as the lifestyle of aid workers operates with a sense of separation from both home and those with them in 'The Field'. Just as there is 'always a name for us' (Woronka 2014, 118), the writers produce this same difference from 'nameless and faceless beneficiaries' (O’Donoghue 2014, 85). However, some also try to disrupt its Othering power; 'Doctors, lawyers and academics. Artists, musicians and poets. These were the 'beneficiaries'” (Woronka, 2014, 118). Seeger $(2014,34)$ highlights and satirises the use of generic terms like 'Beneficiaries' or 'The Community Leaders' to render difference, noting they are remote from the aid worker party scene and must surely 'not have such a strong affection for the Black Eyed Peas'. The subtext, they are not like 'us'.

As Miranda Bryant $(2014,43)$ tells us in her essay 'From New Orleans to South Sudan: How I Healed by Moving to a War-Torn Country', the distancing effect of working in a 'field' overseas can be easier as there is an emotional distance which 
comes with the ability to withdraw, they can 'can buffer themselves from the pain of their beneficiaries experience by virtue of understanding that, theoretically, they can board a plane and leave the disaster when they so choose'. Here it is interesting to note that it is the pain of the experiences that Bryant notes that they are buffered from, while other stories make clear that the difference and separation from the people occupying the spaces in which they work is much deeper and more entrenched.

A number of the essays note the lack of understanding from 'locals' (both staff and otherwise) who question the lifestyle choice to be an 'expat' aid worker (for example, O’Donoghue 2014,82 ). Here gender seems to play an especially important role, particularly the impact of the lifestyle on relationships. In 'Home is Where the Hard is' Caryl Feldacker $(2014,261)$ describes the end of her 'unsalvageable' engagement while in Malawi`, a recurring theme in the essay is the way the engagement 'legitimised our partnership and gave me additional credibility' (263) in the context of the religious conservatism of Malawi. The difference in lifestyle between the motherhood of the 'beneficiaries', repeatedly referenced across the essays, and the decision on the part of the female aid workers to live 'unmoored' lives is a key source of difference, though only rarely explicitly addressed, such as Woronka's $(2014,178)$. regret that; 'I regretted that I had never been married or even been in a serious relationship'.

Romantic relationships (and the lack of them) are a common theme running through a number of the essays, as well as the relationship (or lack of) between the writers and their colleagues and 'beneficiaries'. Reflecting on her own unwillingness to follow her partner to Vancouver, Kelsey Hoppe (2014c, 23) considers the difficulty of connecting to someone else romantically may be part of what inspires her to chase misery: 
We are not the sort of people who go places for other people. We are not people

The idea of seeing 'our lives being lived by another' picks up on a theme explored in the passing literature, that of 'in-group' recognition: that is recognition from the group one has passed from (Robinson 1994). The women's stories in the book perform this function, the women's recognition of each other's passing as aid workers validates their own passing, and their claims to authority. In this way, similar to Sue-Ellen Case's observation of the butch-femme aesthetic $(1988,70)$, 'a strategy of appearances replaces a claim to truth'.

Lucy O'Donoghue's $(2014,80)$ description of aid workers who have 'thoroughly unmoored themselves', who seem 'adrift from any community, at home or on mission', is an interesting counterpoint to Roberta Romano's 'The Subtle Thread' (2014). Romano's essay addresses a growing sense of questioning, found also in Greenhalgh's $(2014,171)$ essay; 'The romance had left almost the instant I arrived, quickly replaces with the feeling of futility that we all tried to forget while commiserating at the local expat bars'. Lisa Smirl (2012) also observed this phenomena in the humanitarian memoirs she analysed; 'as they begin to realise that they are all in a state of ineffectual limbo, where none of their efforts have any impact'.

As this paper has shown, across the essays we see that the female aid worker is always Other, even in their own accounts. Different to, and separated from, those populations they claim to assist and their lives 'back home', searching for the authenticity of experience of 'The Field', and the clarity and validation which its dangers and risks can provide. The following section will explore the sense in which the 
essays highlight the ways the women experience the difference of being female in a profession in which 'most of these stereotypes rest on the assumption that aid workers are male' (Philips 2014, 26).

\section{Passing as an aid worker}

The essays discussed in this paper do not exist in a vacuum, there are broader discourse and narratives from which the writers draw and to which the writers contribute; social imaginaries of the humanitarian sector are already present (for example, see Dechaine 2002; Repo \& Yrjölä 2011). In thinking about the embodied experience of female aid workers, it is necessary to explore how bodies become intelligible in relation to broader discourses and structures. As mentioned earlier, Phillips $(2014,27)$ highlights that the common assumption is that the aid worker is male. The women in the essays confirm this sense of only 'passing as' aid workers in relation to the 'real' (male) aid workers, this sense of being out of place as a women in the essays is linked to notions of their newness, inexperience and lack (or not) of toughness.

Philips $(2014,25)$ communicates this through the story of her experience at Nairobi's Jomo Kenyatta airport, where she thought she 'had ended my aid career before it even began' over an alarm clock which 'looked suspiciously like handcuffs' on the security x-ray. It is not the situation but Philips's (25) reaction to it which causes the problem, 'I was surrounded by other conflict-weary, khaki-wearing aid workers who were mostly men and I feared I had committed a fatal error [crying] that highlighted both my newness and my gender'. For Philips, her gender is a deficiency for humanitarian work on a par with her lack of experience. It is not simply the fact of her gender, but the physical manifestation of this in her tears and near-hysteria. She has failed to pass in this instance and the manner of her failure highlights that the 'sense of 
being inadequate to the identity one assumes (either consciously or unconsciously) involves phantasies about who is the real or authentic subject' (Ahmed 1999, 96). In the essays, we repeatedly see fantasies about what authenticates a 'real' aid worker.

Again, difference is produced for the women in their stories through juxtaposing their extraordinary lives to the lives of those around them as well as to the more experienced, more 'real' aid workers. Gaanderse $(2014,137)$ tackles this in her essay in which she found herself, 'the girl from headquarters who was bringing a whole household with her to a refugee settlement' subject to the 'mocking stares and incredulous glances - especially from local male colleagues'. She recalls thinking 'I am tougher than they think'. The issue of 'toughness' as a norm or standard of what makes a 'real' aid worker also appears in O'Donoghue's $(2014,79)$ essay. She notes the persona she tried to embody, 'a fusion of ruthless efficiency and hakuna matata, and it felt like the result was one scratchy, cynical, impatient bitch'. This strategy of passing is common, 'a technique of the self' (Ahmed 1999, 101) in which the passer adopts elements of the identity one is trying to pass as and projects a particular bodily image. In describing the attempts of the women to adopt the identity of aid worker, the stories reveal the fetish of the aid worker identity. The women do the work of identifying the elements of the identity which reveal difference from their own; in 'desiring to capture an identity...[i]t takes time and knowledge to see the difference that one may desire (or need) to become' (98).

Seeger $(2014,31)$ highlights an important aspect of the notion of 'realness' in relation to aid work: its relationship to a specific aesthetic of dustiness and dirt. She highlights this, noting the 'professional suicide' of a stylish haircut which a 'real' aid worker would not have time for. The spectre of 'real' (masculine) aid workers haunts ${ }^{\mathrm{vi}}$ many of the stories. For Philips $(2014,25)$, it was the khaki-wearing (male) veteran aid 
workers at the airport who seems to share much in common with Romano's $(2014,201)$ Austrian 'security guy that wears trousers full of pockets and you are sure he keeps knives and compasses in some of them'. Seeger $(2014,32)$ speaks of the 'infamous [Russian] helicopter pilots about whom every veteran aid worker seems to have a story'. For Roberson $(2014,62)$ it is the 'big, burly South African and Zimbabwean ex-military men, who knew how to drink and have more fun than anyone else I have ever met' from the landmine NGO. And for Greenhalgh $(2014,173)$, it was the 'WPF guys [who] tolerated our presence, using it as a chance to gossip and flirt'.

As Ahmed $(2017,122)$ notes of passing, 'it can be uncomfortable' to not be able to embody established norms and the discomfort of the failure to pass can also be found in the essays, often made visible by the specific discomforts of female aid workers. This is a theme also explored in Partis-Jennings' $(2017,418)$, account of the gendered security practices of peacebuilding in Afghanistan, in which many highlighted 'restriction, harassment or self-enforces security measures based on gender'. Greenhalgh $(2014,172)$ supplements the general discomfort of 'The Field' with the particular discomfort of being a woman there; the 'unfriendly locals who catcalled'. Gaanderse also highlights this $(2014,138-139)$, she describes the awkwardness of the showers being situated next to the contingent of the Uganda Police Force, there to protect them, as she 'began to wonder whether stripping down in the dark next to a group of half-drunk, undressed, male police officers was really such a good idea.'

A similar problem is observed in Ali's essay $(2014,51)$, in which she is hungry and thirsty 'but what goes in must come out, and there's no privacy for a woman at the side of these roads'. Ali's dilemma is compounded by the threat of landmines away from the road where privacy could be found. My intent here is not to claim that women have it worse, but to draw attention to the specific and embodied differences which alter 
how they experience 'The Field' and to suggest that we need to ask more about these differences and the effects they have on practices of peacebuilding and humanitarianism.

As Phillips' story of her airport experience highlights, women's apparent propensity for tears marks them as different. As Hoppe $(2014,12)$ notes in the preface to the book, 'women are more apt to cry, or at least admit to crying', however, she frames this as 'often the only appropriate response' to human suffering. Yet, it is often the personal miseries in the essays which lead to tears: Philips at the airport; Woronka falling out with a colleague (2014); Gaanderse $(2014,135)$ 'the crying aid worker', emotional at leaving; and Hoppe $(2014,220)$ with relief at seeing a colleague during a difficult time.

The juxtaposition between tears as the appropriate response to human misery and the actual instances of their own crying detailed by the women reflects the concern, discussed in the preface to Chasing Misery, that telling the aid worker story 'detracts from the stories of those we have gone to help or those who are 'truly' suffering' (Hoppe 2014b, 11-12). The goal of the book, to stand in solidarity with those 'truly' suffering by attempting to 'tell your story through my story' (12), presents a community in which crying is affirmed as an 'appropriate' response, and in doing so the authors also affirm their membership of a community of female aid workers. This affords them a collective voice through which they challenges the assumed superiority of the masculinity and 'maleness' of the aid worker identity, from a position of authority which their experience of 'The Field' grants them.

\section{Concluding thoughts: women as flesh witnesses in humanitarianism}

This paper explores what we can learn about embodied difference in humanitarianism and peacebuilding by taking seriously women's memoirs as a form of 'flesh witnessing' 
(Harari 2009). A focus on humanitarian memoirs, representing "their story as they want to tell it' (Duncanson 2013, 57), builds on the important feminist research done on military memoirs, especially Dyvick (2016a; 2016b; see also, Welland 2015;

Duncanson 2009); embodiment in peace and conflict studies (Partis-Jennings 2017; Wilcox 2015; Sylvester, 2013); and Lisa Smirl's work on liminality in humanitarian memoirs (Smirl 2012). Drawing on the notion of 'flesh witnessing', I have argued that the essays in Chasing Misery (Hoppe 2014a) collection are simultaneously claims to speak with authority of 'The Field' but also reveal the sense to which the women feel they are only 'passing' as aid workers.

In this paper, I noted in particular three themes of difference, beginning with the construction of 'The Field' as a site of embodied authority and explored the ways in which the women's essays reinforced and troubled this notion. I then noted the ways in which the writers highlighted feeling different from, and separate to, the people they work with and for. They highlight the generalising terminology and the effect of this on the possibility of forming genuine relationships. Relationships are also foregrounded as a site of difference but very much connected to their identity as aid workers 'chasing misery'. Finally, I explored the ways in which their embodied gender caused the writers to note their difference from an imagined aid worker, revealing a sense in which the women were only passing as aid workers. The fragility of the imagined identity itself is thus revealed in the collective narration of their experiences as female aid workers.

The article makes an original contribution to the literature on humanitarianism and peacebuilding, drawing on the under-researched humanitarian memoir. In doing so it highlights the curious absence of analyses of humanitarian aid which take gender seriously as a category of analysis, rather than simply a programming area. In highlighting the attempts of female aid workers to narrate their distinct experiences, it 
foreground embodied experience as key to a consideration of the complex power structures and relationships in humanitarianism and peacebuilding. The tendency to view the international/local distinction as the primary category of difference in humanitarianism and peacebuilding, obscures the complex and intersecting hierarchies of gender, race, class, nationality and age which are deeply embedded in humanitarian practices. Though the focus here has been on how gender difference is narrated by female aid workers as a starting point, analyses of this kind can also reveal important insights about these other categories of difference.

As a final point, I want to note that these memoirs must be viewed as shaping and shaped by broader social imaginaries. Just as explorers' travel writing has 'produced the rest of the world' for European audiences since the 1700s (Pratt 2008, 5), because "it functions to introduce "us" to the Other. This equally affords us a way of knowing ourselves' (Heron, 2007: 3). Memoirs of humanitarianism and peacebuilding perform the same function, introducing humanitarian spaces to Northern audiences, in order that they are reassured that 'Northern countries have a special role to play in alleviating the woes of the poor global others' (ibid, 5). Yet, while the essays in Chasing Misery (Hoppe 2014a) perform this function, and are firmly embedded in global structures and relationships of power, and this analysis has demonstrated the ways in which the women also trouble these discourses, by recognising them at work. By focusing on gender as a site of difference, the women present a community which affords them a collective voice through which they challenge dominant tropes of aid, from a position of authority which their experience of 'The Field' grants them. In doing so, they trouble the dominant narrative of noble aid workers, by recognising the paradox of self-fulfilment they receive from their apparent altruism, as Kelsey Hoppe puts it (2014c, 23), 'We are in love with ourselves. We are in love with the idea of ourselves.' 
The book sought to stand in solidarity with those 'truly' suffering by attempting to 'tell and Othering which plague the humanitarian system.

Acknowledgements: I would like to thank the editors of this special issue, Pol Bargués-Pedreny and Xavier Mathieu, for the opportunity to be part of such a rewarding collaboration, as well as the other contibuotrs to the workshop from which this special issue came, especially Nicolas Lemay-Hébert. I thank the two anonymous reviewers for their helpful and generous suggestions, in particular the recommendation to engage with the work of Hannah PartisJennings, whom I would also like thank. The idea for this piece came from my participation in a workshop organised Laura Mcleod and Maria O'Rielly in 2016 on feminist interventions in critical peacebuilding, I thank them for the inspiration.

\section{References}

Abdelnour, S., and A. M. Saeed. 2014. "Technologizing Humanitarian Space: Darfur Advocacy and the Rape-Stove Panacea.” International Political Sociology, 8(2): 145-163. http://doi.org/10.1111/ips.12049

Agier, M. 2010. "Humanity as an Identity and Its Political Effects (A Note on Camps and Humanitarian Government)". Humanity: An International Journal of Human Rights, Humanitarianism, and Development, 1(1): 29-45. http://doi.org/10.1353/hum.2010.0005

Ahmed, Sara. 1999. "“She”ll Wake Up One of These Days and Find She's Turned into a Nigger’: Passing Through Hybridity." Theory, Culture \& Society, 16(2): 87106.

Ahmed, Sara. 2017 Living a Feminsit Life. London: Duke University Press.

Ali, Mia. 2014. "Built to Carry Thirteen”. In Chasing Misery: an anthology of essays by women in humanitarian responses, edited by Kelsey Hoppe, 51-60. CreateSpace Independent Publishing Platform.

Autesserre, Séverine. 2014. Peaceland: Conflict Resolution an the Everyday Politics of International Intervention. Cambridge: Cambridge University Press.

Baker, Catherine. 2016. "Writing About Embodiment as an Act of Translation.” Critical Military Studies, 2(1-2), 120-124. 
Bargués-Pedreny, Pol and Xavier Mathieu .2018. "Beyond Silence, Obstacle and Stigma: Revisiting the 'Problem' of Difference in Peacebuilding”, Journal of Intervention and Statebuilding 12 (3).

Bryant, Miranda. 2014. From New Orleans to South Sudan: How I Healed by Moving to a War-Torn Country. In Chasing Misery: an anthology of essays by women in humanitarian responses, edited by Kelsey Hoppe, 41-46. CreateSpace Independent Publishing Platform.

Case, S.-E. 1988. "Towards a Butch-Femme Aesthetic". Discourses, 11(1), 55-73.

Conboy, K., N. Medina and S. Stanbury. 1997. "Introduction". In Writing on the Body: female embodiment and feminist theory, edited by K. Conboy, N. Medina and S. Stanbury, 1-12. New York, NY: Columbia University Press.

Dechaine, D. R. 2002. "Humanitarian Space and the Social Imaginary: Medecins Sans Frontieres/Doctors Without Borders and the Rhetoric of Global Community." Journal of Communication Inquiry, 26(4), 354-369. http://doi.org/10.1177/019685902236896

Donovan, K. P. 2015. “Infrastructuring Aid: Materializing Humanitarianism in Northern Kenya." Environment and Planning D: Society and Space, 33(4), 732-748. http://doi.org/10.1177/0263775815598107

Duffield, Mark. 2010. "Risk-Management and the Fortified Aid Compound: Everyday Life in Post-Interventionary Society". Journal of Intervention and Statebuilding, $4(4), 453-474$.

Duffield, Mark. 2010). “The Liberal Way of Development and the DevelopmentSecurity Impasse: Exploring the Global Life-Chance Divide.” Security Dialogue, 41(1), 53-76. http://doi.org/10.1177/0967010609357042

Duffield, Mark. 2012. "Challenging Environments: Danger, Resilience and the Aid Industry." Security Dialogue, 43(5), 475-492.

Duncanson, Claire. 2009. "Forces for Good? Narratives of Military Masculinity in Peacekeeping Operations." International Feminist Journal of Politics, 11(1), 63-80. http://doi.org/10.1080/14616740802567808

Dyvik, Synne. L. 2016a. "Of Bats and Bodies: Methods for Reading and Writing Embodiment." Critical Military Studies, 2(1-2), 56-69.

Dyvik, Synne. L. 2016b. “'Valhalla Rising': Gender, Embodiment and Experience in Military Memoirs.” Security Dialogue, 47(2), 133-150. http://doi.org/10.1177/0967010615615730 
Fast, Larissa. 2014. Aid in Danger: The Perils and Promise of Humanitarianism. Philadelphia, PA: University of Pennsylvania Press.

Feldacker, Caryl. 2014. "Home Is Where The Hard Is.” In Chasing Misery: an anthology of essays by women in humanitarian responses, edited by Kelsey Hoppe, 261-273. CreateSpace Independent Publishing Platform.

Gaanderse, Miranda. 2014. "Send In The Clown. In Chasing Misery: an anthology of essays by women in humanitarian responses, edited by Kelsey Hoppe, 135-148. CreateSpace Independent Publishing Platform.

Givoni, M. 2011. "Beyond the Humanitarian/Political Divide: Witnessing and the Making of Humanitarian Ethics.” Journal of Human Rights, 10(1), 55-75.

Greenhalgh, Emilie J. 2014. “Answers Found In Harm’s Way: From Congo To Afghanistan." In Chasing Misery: an anthology of essays by women in humanitarian responses, editied by Kelsey Hoppe, 167-180. CreateSpace Independent Publishing Platform.

Hagon, Kirsten. 2014. “There Is No Rape In Darfur.” In Chasing Misery: an anthology of essays by women in humanitarian responses, edited by Kelsey Hoppe, 241254. CreateSpace Independent Publishing Platform.

Harari, Y. N. 2009. "Scholars, Eyewitnesses, and Flesh-Witnesses of War: A tense relationship." Partial Answers: Journal of Literature and the History of Ideas, 7(2), 213-228.

Heron, Barbara. 2007. Desire for Development: Whiteness, Gender and the Helping Imperitive. Ontario, Canada: Wilfrid Laurier University Press.

Hoppe, Kelsey, ed. 2014a. Chasing Misery: an anthology of essays by women in humanitarian responses. CreateSpace Independent Publishing Platform.

Hoppe, Kelsey. 2014b. "Preface”. In Chasing Misery: an anthology of essays by women in humanitarian responses, edited by Kelsey Hoppe, 11-15. CreateSpace Independent Publishing Platform.

Hoppe, Kelsey. 2014c. "Chasing Misery”. In Chasing Misery: an anthology of essays by women in humanitarian responses, edited by Kelsey Hoppe, 21-24. CreateSpace Independent Publishing Platform.

Hoppe, Kelsey. 2014e. "I Know What Fear Tastes Like.” In Chasing Misery: an anthology of essays by women in humanitarian responses, edited by Kelsey Hoppe, 210-220. CreateSpace Independent Publishing Platform. 
Hubbard, Rachael. 2014. “The Great North Road.” In Chasing Misery: an anthology of essays by women in humanitarian responses, edited by Kelsey Hoppe, 151-158. CreateSpace Independent Publishing Platform.

Joseph, Jonathan. 2018. "Beyond Relationalism in Peacebuilding." Journal of Intervention and Statebuilding 12 (3).

Mac Ginty, Roger .2010. "Hybrid Peace: The Interaction Between Top-Down and Bottom-Up Peace." Security Dialogue, 41(4), 391-412. http://doi.org/10.1177/0967010610374312

Mac Ginty, Roger. 2017. A Material Turn in International Relations: The 4x4, Intervention and Resistance. Review of International Studies, Online, 1-20. http://doi.org/10.1017/S0260210517000146

Mac Ginty, Roger. And Oliver Richmond. 2015. “The Fallacy of Constructing Hybrid Political Orders: A Reappraisal of the Hybrid Turn in Peacebuilding." International Peacekeeping, 3312(November), 1-21. http://doi.org/10.1080/13533312.2015.1099440

McLeod, Laura. 2015. "A Feminist Approach to Hybridity: Understanding Local and International Interactions in Producing Post-conflict Gender Security.” Journal of Intervention and Statebuilding 9 (1): 48-69. http://dx.doi.org/10.1080/17502977.2014.980112

Martin de Almagro, Maria. 2018. "Hybrid Clubs: A Feminist Approach to Peacebuilding in the Democratic Republic of Congo" Journal of Intervention and Statebuilding 12 (3).

Martin de Almagro, Maria. 2017. "Producing Participants: Gender, Race, Class, and Women, Peace and Security." Global Society Online. https://doi.org/10.1080/13600826.2017.1380610

O’Donoghue, Lucy. 2014. "Relationships: At the heart of, well, everything.” In Chasing Misery: an anthology of essays by women in humanitarian responses, edited by Kelsey Hoppe, pp. 79-85. CreateSpace Independent Publishing Platform.

O'Heir, Tracy. 2014. "Beating the Odds." In Chasing Misery: an anthology of essays by women in humanitarian responses, edited by Kelsey Hoppe, 71-78. CreateSpace Independent Publishing Platform.

Older, Malka. 2014. “Accepting Thanks.” In Chasing Misery: an anthology of essays by women in humanitarian responses, edited by Kelsey Hoppe, 295-301. CreateSpace Independent Publishing Platform. 
Partis Jennings, Hannah. 2017. “The (In)Security of Gender in Afghanistan’s peacebuilding project: Hybridity and Affect." International Feminist Journal of Politics 19(4): 411-425. https://doi.org/10.1080/14616742.2017.1279418

Pratt, Mary Louise. 2008. Imperial Eyes: Travel Writing and Transculturation. $2^{\text {nd }}$ ed. Abingdon: Routledge.

Philips, Melissa. 2014. "Real Women in Aid Work: Must We Be Either Angelina Jolie or Mother Theresa? In Chasing Misery: an anthology of essays by women in humanitarian responses, edited by Kelsey Hoppe, 25-29). CreateSpace Independent Publishing Platform.

Randazzo, E. 2016. "The Paradoxes Of The "Everyday": Scrutinising The Local Turn In Peace Building". Third World Quarterly, 6597(March), 1-20. http://doi.org/10.1080/01436597.2015.1120154

Redfield, Peter. 2016. "Fluid Technologies: The Bush Pump, the LifeStraw ${ }^{\circledR}$ and Microworlds of Humanitarian Design.” Social Studies of Science, 46(2), 159183. http://doi.org/10.1177/0306312715620061

Repo, J., and R. Yrjölä. 2011. "The Gender Politics of Celebrity Humanitarianism in Africa." International Feminist Journal of Politics, 13(1), 44-62. http://doi.org/10.1080/14616742.2011.534661

Richmond, Oliver, Stefanie Kappler and Annika Björkdahl. 2015. "The "Field" in the Age of Intervention: Power, Legitimacy, and Authority Versus the "Local."” Millennium - Journal of International Studies, 44(1), 23-44. http://doi.org/10.1177/0305829815594871

Rieff, David. 2002. A Bed For The Night: Humanitarianism In Crisis. London: Vintage. Roberson, Steph. 2014. "Falling Down.” In Chasing Misery: an anthology of essays by women in humanitarian responses, edited by Kelsey Hoppe, 61-69. CreateSpace Independent Publishing Platform.

Robinson, A. 1994. "It Takes One to Know One: Passing and Communities of Common Interest." Critical Inquiry, 20(4), 715-736.

Romano, Roberta. 2014. "The Subtle Thread." In Chasing Misery: an anthology of essays by women in humanitarian responses, edited by Kelsey Hoppe, 199-207. CreateSpace Independent Publishing Platform.

Roth, Silke. 2014. "Aid Work as Edgework - Voluntary Risk-Taking and Security in Humanitarian Assistance, Development and Human Rights Work.” Journal of Risk Research, 18(2), 139-155. http://doi.org/10.1080/13669877.2013.875934 
Scott-Smith, Tom. 2013. "The Fetishism of Humanitarian Objects and the Management of Malnutrition in Emergencies. Third World Quarterly, 34(5), 913-928. http://doi.org/10.1080/01436597.2013.800749

Seeger, Helen. 2014. “The Field: The Ever Receeding Vanishing Point.” In Chasing Misery: an anthology of essays by women in humanitarian responses, edited by Kelsey Hoppe, 31-35. CreateSpace Independent Publishing Platform.

Sheehan, Carman. 2014. "No Place." In Chasing Misery: an anthology of essays by women in humanitarian responses, edited by Kelsey Hoppe, 226-240. CreateSpace Independent Publishing Platform.

Smirl, Lisa. 2008. "Building The Other, Constructing Ourselves: Spatial Dimensions of International Humanitarian Response. International Political Sociology, 2(3), 236-253.

Smirl, Lisa. 2012. “The State We Are(n’t) In: Liminal Subjectivity in Aid Worker Biographies." In Statebuilding and State Formation: the political sociology of intervention, edited by Berit Bliessman de Guevara, 230-245. London: Routledge.

Smirl, Lisa. 2015. Spaces of Aid: How Cars, Compounds and Hotels Shape Humanitarianism. London: Zed Books.

Smirl, Lisa. 2016. “"Not Welcome at the Holiday Inn”: How a Sarajevan Hotel Influenced Geo-politics.” Journal of Intervention and Statebuilding, 2977(February), 1-24. http://doi.org/10.1080/17502977.2015.1137398

Sylvester, Christine. 2013. War as Experience: contributions from international relations and feminist analysis. Abingdon: Routledge.

Ticktin, Miriam. 2011. “The gendered human of humanitarianism: Medicalising and politicising sexual violence." Gender and History, 23(2), 250-265. http://doi.org/10.1111/j.1468-0424.2011.01637.x

Townley, Ruth. 2014. "Holding Their Stories.” In Chasing Misery: an anthology of essays by women in humanitarian responses, edited by Kelsey Hoppe, 127-134. CreateSpace Independent Publishing Platform.

Welland, Julia. 2013. "Militarised Violences, Basic Training, and The Myths of Asexuality and Discipline.” Review of International Studies 39(4), 881-902. http://doi.org/10.1017/S0260210512000605 
Welland, Julia. 2015. "Liberal Warriors and the Violent Colonial Logics of "Partnering and Advising."'" International Feminist Journal of Politics, 17(2): 289-307 http://doi.org/10.1080/14616742.2014.890775

Wilcox, Lauren. B. (2015). Bodies of Violence: Theorizing Embodied Subjects in International Relations. Oxford: Oxford University Press.

Woronka, Kati. 2014. “Of Pastries, Loss, and Pride.” In Chasing Misery: an anthology of essays by women in humanitarian responses, edited by Kelsey Hoppe, 115122. CreateSpace Independent Publishing Platform.

${ }^{\mathrm{i}}$ The book also features photographic contributions but these have not been included in this analysis as they are not examples of aid workers narrating their own experiences. The photographs are not of the contributor women themselves but rather of those they are 'aiding'.

ii I want to thank Xavier Mathieu for his extremely helpful suggestion to explore this literature.

iii Kelsey Hoppe contribute three essays, including the introduction and Helen Seeger contributes two essays to the collection.

iv Though not all authors chose to share the information about their nationality, of those that do, most are from the UK, Europe, Australia, New Zealand and the US.

${ }^{v}$ Though here the clothes are a metaphor, in this issue, Maria Martin de Almagro explores they ways that clothes are used in performances of hybrid peacebuilding identities (see also, Partis-Jennings, 2017, 419).

${ }^{\text {vi }}$ For more on hauntings and masculinities, see Welland, 2013. 